Supporting Information

for

\title{
Modulation of Redox Signalling and Thiol Homeostasis in Red Blood Cells by Peroxiredoxin Mimetics
}

\author{
Gaurango Chakrabarty, Somanathapura K. NaveenKumar, Sagar Kumar and \\ Govindasamy Mugesh*
}


Table of Contents

\begin{tabular}{|c|c|c|c|c|}
\hline S. No & Cont & nts & & Page No \\
\hline 1.1 & Mate & ials and & General Experimental Conditions & 01 \\
\hline & 1.2 & Synthe & c procedures of selenium compounds & 01 \\
\hline & & 1.2 .1 & Synthesis of S2 & 01 \\
\hline & & 1.2 .2 & Synthesis of S4 & 01 \\
\hline & & 1.2 .3 & Synthesis of 4 & 01 \\
\hline & & 1.2 .4 & Synthesis of 1 & 02 \\
\hline & & 1.2 .5 & Synthesis of S5 & 02 \\
\hline & & 1.2 .6 & Synthesis of S6 & 03 \\
\hline & & 1.2 .7 & Synthesis of S7 & 03 \\
\hline & & 1.2 .8 & Synthesis of 5 & 03 \\
\hline & & 1.2 .9 & Synthesis of 2 & 03 \\
\hline & & 1.2 .10 & Synthesis of 6 & 04 \\
\hline & & 1.2 .11 & Synthesis of S9 & 04 \\
\hline & & 1.2 .12 & Synthesis of S10 & 05 \\
\hline & & 1.2 .13 & Synthesis of 7 & 05 \\
\hline & & 1.2 .14 & Synthesis of 11 & 05 \\
\hline & & 1.2 .15 & Synthesis of 12 & 05 \\
\hline & & 1.2 .16 & Synthesis of 8 & 06 \\
\hline & & 1.2 .17 & Synthesis of S13 & 06 \\
\hline & & 1.2 .18 & Synthesis of 9 & 07 \\
\hline & & 1.2 .19 & Synthesis of 10 & 07 \\
\hline & 2.1 & Determ & nation of methemoglobin level & 08 \\
\hline & 2.2 & Evalua & on of t-BuOOH-induced cytotoxicity & 08 \\
\hline 3 & Char & cterizat & on and cellular studies & 08 \\
\hline & 3.1 & NMR $(1$ & $-{ }^{13} \mathrm{C}$ NMR and ${ }^{77} \mathrm{Se}$ ) spectra of compound 2 & 08 \\
\hline & 3.2 & NMR $(1$ & $-{ }^{13} \mathrm{C}$ NMR and ${ }^{77} \mathrm{Se}$ ) spectra of compound 4 & 10 \\
\hline & 3.3 & NMR $(1$ & -1, ${ }^{13} \mathrm{C}$ NMR and ${ }^{77} \mathrm{Se}$ ) spectra of compound 5 & 11 \\
\hline & 3.4 & NMR $(1$ & -1, ${ }^{13} \mathrm{C} \mathrm{NMR}$ and ${ }^{77} \mathrm{Se}$ ) spectra of compound 6 & 13 \\
\hline & 3.5 & NMR $(1$ & $\mathrm{H},{ }^{13} \mathrm{C}$ NMR and ${ }^{77} \mathrm{Se}$ ) spectra of compound 8 & 14 \\
\hline & 3.6 & NMR $(1$ & $-{ }^{13} \mathrm{C}$ NMR and ${ }^{77} \mathrm{Se}$ ) spectra of compound $\mathbf{9}$ & 16 \\
\hline & 3.7 & NMR $(1$ & $\mathrm{H},{ }^{13} \mathrm{C}$ NMR and ${ }^{77} \mathrm{Se}$ ) spectra of compound 10 & 17 \\
\hline & 3.8 & NMR $(1$ & $-1,{ }^{13} \mathrm{C}$ NMR and $\left.{ }^{77} \mathrm{Se}\right)$ spectra of compound 11 & 19 \\
\hline & 3.9 & NMR $(1$ & $\mathrm{H},{ }^{13} \mathrm{C}$ NMR and $\left.{ }^{77} \mathrm{Se}\right)$ spectra of compound 12 & 20 \\
\hline & 3.10 & NMR $(1$ & $\mathrm{H},{ }^{13} \mathrm{C}$ NMR and $\left.{ }^{77} \mathrm{Se}\right)$ spectra of compound 13 & 22 \\
\hline & 3.11 & Dose-d & pendent effect of Se-compounds on $\mathrm{H}_{2} \mathrm{O}_{2}$-induced eryptosis & 24 \\
\hline & 3.12 & The rel & tive cell viability of RBCs treated with selenium compounds & 25 \\
\hline & 3.13 & Estima & on of catalase, GR and TrxR activities in the presence of specific inhibitors & 26 \\
\hline & 3.14 & $\begin{array}{l}\text { Flow cy } \\
\text { with co }\end{array}$ & $\begin{array}{l}\text { ometric analysis of intracellular } \mathrm{Ca}^{2+} \text { and PS externalization in RBCs treated } \\
\text { oidin- } \mathrm{A} \text { or conoidin- } \mathrm{A}+\mathrm{H}_{2} \mathrm{O}_{2} \text { in the presence of Se-compounds }\end{array}$ & 27 \\
\hline & 3.15 & $\begin{array}{l}\text { Confoc } \\
\text { presen }\end{array}$ & $\begin{array}{l}\text { I microscopy images of RBCs treated with conoidin- } \mathrm{A}+\mathrm{H}_{2} \mathrm{O}_{2} \text { in the } \\
\text { e of Se-compounds }\end{array}$ & 29 \\
\hline & 3.16 & Expres & ion and purification of thioredoxin (Trx)-His in E.coli. & 30 \\
\hline 4 & Refer & ences & & 31 \\
\hline
\end{tabular}




\subsection{Materials and methods}

All the chemicals were obtained from Sigma or from local suppliers. Ebselen (13) was synthesized by following a procedure reported earlier. ${ }^{1}$ All the reactions were carried out in well-ventilated fume hoods. Selenium-based reactions were carried out under nitrogen using standard vacuum-line techniques. Thin layer chromatography analyses were carried out on pre-coated silica gel plates (Merck), and spots were visualized with UV-radiation or staining with iodine. Column chromatography was performed on glass columns loaded with silica gel (230-400 mesh) or on an automated flash chromatography systems (Biotage) with use of pre-loaded silica cartridges. ${ }^{1} \mathrm{H}(400 \mathrm{MHz}),{ }^{13} \mathrm{C}(100$ $\mathrm{MHz})$ and ${ }^{77} \mathrm{Se}$ NMR $(76.28 \mathrm{MHz})$ spectra were obtained on a Bruker $400 \mathrm{MHz}$ NMR spectrometer. Chemical shifts are cited with respect to $\mathrm{SiMe}_{4}$ as internal $\left({ }^{1} \mathrm{H}\right.$ and $\left.{ }^{13} \mathrm{C}\right)$ and $\mathrm{Me}_{2} \mathrm{Se}$ as external $\left({ }^{77} \mathrm{Se}\right)$ standard. Mass spectral studies were carried out on a Bruker Daltronics Esquire 6000 plus mass spectrometer with ESI-MS mode analysis. Elemental analysis was performed on a Thermo Scientific Flash 2000 organic elemental analyzer.

\subsection{Synthesis of selenium compounds}

1.2.1. Synthesis of S2. p-Methoxybenzyl diselenide (S1) was synthesized by following a method reported by Kleymann and Griffin. ${ }^{2}$ The diselenide was reduced to the corresponding selenol in situ as follows: To a solution of p-methoxybenzyl diselenide (S1) in DMF was treated with an excess amount of sodium borohydride at $0{ }^{\circ} \mathrm{C}$ under strictly nitrogen atmosphere. An immediate color change from orange to pale yellow was observed. The reaction mixture was stirred for $10 \mathrm{~min}$ and the resulting selenol $\mathbf{S} 2$ was used for the next step without any purification.

1.2.2. Synthesis of S4. A solution of the tosylated compound $\mathbf{S} 3(200 \mathrm{mg}, 0.42 \mathrm{mmol})$ in dry DMF (purged with $\mathrm{N}_{2}$ gas) was added dropwise via syringe for a period of $20 \mathrm{~min}$ to a freshly prepared solution of $\mathbf{S 2}(0.90 \mathrm{mmol})$ at $0{ }^{\circ} \mathrm{C}$. The ice-bath was removed and the stirring was continued at room temperature under nitrogen atmosphere until all the starting material gets consumed (TLC analysis). Water was added and the resulting suspension was extracted with ethyl acetate $(2 \times 25 \mathrm{~mL})$. The combined organic layer was washed with brine, dried over anhydrous $\mathrm{Na}_{2} \mathrm{SO}_{4}$, and evaporated to obtain the crude product as yellow oil. The desired compound was purified using column chromatography (silica-gel, 20:80 EtOAc:petroleum ether). Compound $\mathbf{S 4}$ was obtained as a paleyellow oil in 95\% yield $(213 \mathrm{mg}) .{ }^{1} \mathrm{H}$ NMR $\left(\mathrm{CDCl}_{3}\right) \delta(\mathrm{ppm}): 1.41(\mathrm{~s}, 6 \mathrm{H}), 2.58-2.68(\mathrm{~m}, 4 \mathrm{H}), 3.78(\mathrm{~s}$, $6 \mathrm{H}), 3.80(\mathrm{~d}, 4 \mathrm{H}, \mathrm{J}=3.0 \mathrm{~Hz}), 3.87-3.88(\mathrm{~m}, 2 \mathrm{H}), 6.81-6.84(\mathrm{~m}, 4 \mathrm{H}), 7.20-7.26(\mathrm{~m}, 4 \mathrm{H}) ;{ }^{13} \mathrm{C} N M R$ $\left(\mathrm{CDCl}_{3}\right) \delta(\mathrm{ppm}): 25.7,27.8,27.86,55.7,81.2,109.3,114.4,130.5,131.4,158.9 ;{ }^{77} \mathrm{Se} \mathrm{NMR}\left(\mathrm{CDCl}_{3}\right) \delta$ (ppm):223.

1.2.3. Synthesis of 4 . To a solution of iodine $(101 \mathrm{mg}, 0.39 \mathrm{mmol})$ in $\mathrm{MeOH}(5 \mathrm{~mL})$ and $\mathrm{H}_{2} \mathrm{O}(1 \mathrm{~mL})$, a solution of $\mathbf{S} 4$ (70 mg, $0.13 \mathrm{mmol})$ in THF $(5 \mathrm{~mL})$ was added dropwise over a period of $15 \mathrm{~min}$. After an additional $5 \mathrm{~min}$ of stirring at room temperature $\left(34^{\circ} \mathrm{C}\right)$, an aqueous $1 \mathrm{M}$ solution of hydrazine hydrate $(1 \mathrm{~mL})$ was added to the reaction mixture to quench the excess iodine. The mixture was then extracted with ethyl acetate $(3 \times 25 \mathrm{~mL})$. The combined organic layer was washed with water and 
brine, dried over anhydrous $\mathrm{Na}_{2} \mathrm{SO}_{4}$ and evaporated to give the crude product as yellow oil. Column chromatography over silica gel (20:80 ethyl acetate:petroleum ether) gave the desired compound $\mathbf{4}$ as yellow solid in $76 \%$ yield $(28.7 \mathrm{mg}){ }^{1} \mathrm{H}$ NMR $\left(\mathrm{CDCl}_{3}\right) \delta(\mathrm{ppm}): 1.40(\mathrm{~s}, 6 \mathrm{H}), 3.26-3.35(\mathrm{~m}, 4 \mathrm{H}), 3.67-$ $3.69(\mathrm{~m}, 2 \mathrm{H}) ;{ }^{13} \mathrm{C} \mathrm{NMR}\left(\mathrm{CDCl}_{3}\right) \delta(\mathrm{ppm}): 27.3,28.7,79.8,105.2 ;{ }^{77} \mathrm{Se} \mathrm{NMR}\left(\mathrm{CDCl}_{3}\right) \delta(\mathrm{ppm}): 282 ;$ Anal. Calcd for $\mathrm{C}_{7} \mathrm{H}_{12} \mathrm{O}_{2} \mathrm{Se}_{2}$ : C, 29.39; $\mathrm{H}, 4$.23. Found: $\mathrm{C}, 29.38 ; \mathrm{H}, 4.26$.

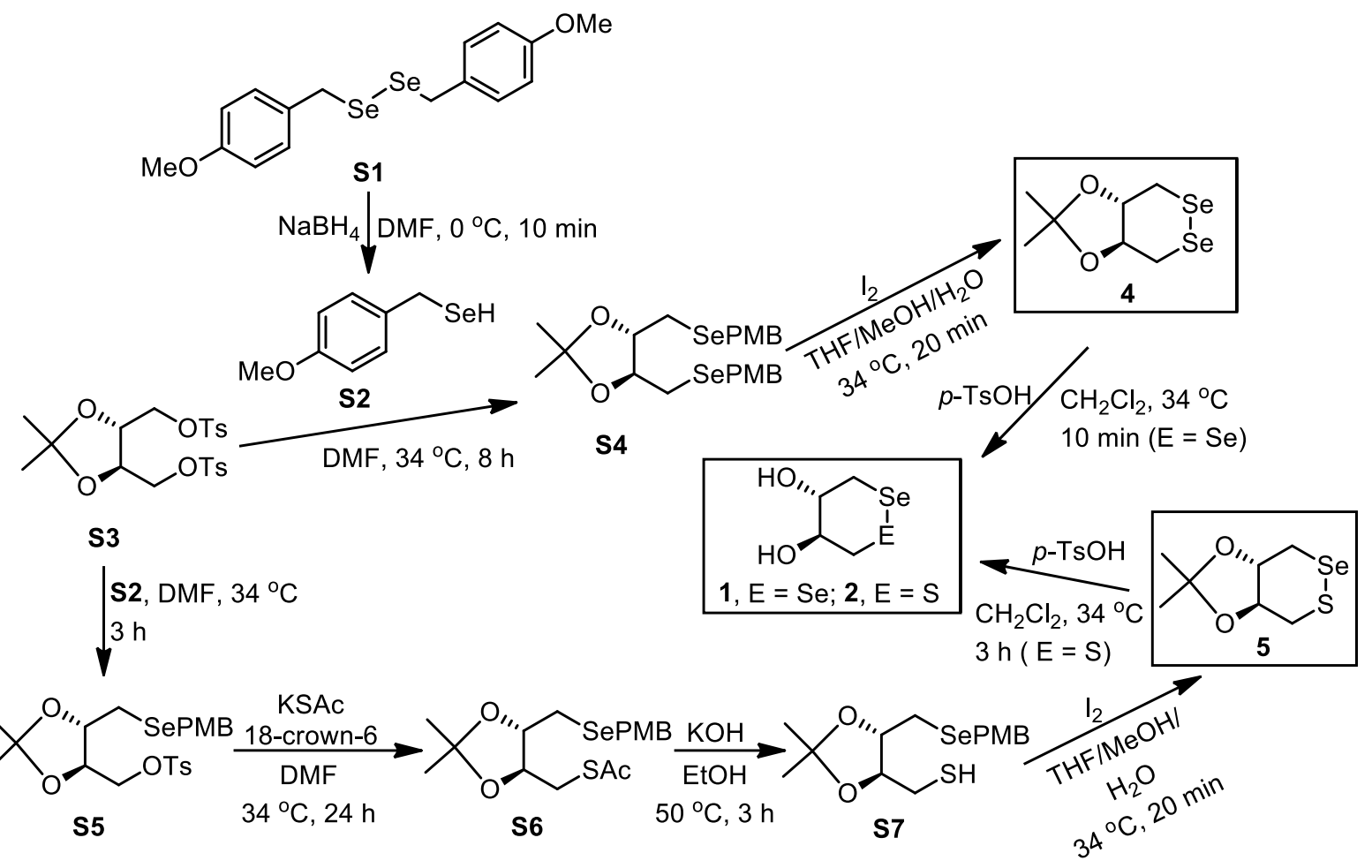

Scheme S1. Chemical synthesis of the intramolecular diselenides and selenenyl sulfides 1,2,4 and 5 .

1.2.4. Synthesis of $1 .^{3 \mathrm{a}, \mathrm{c}} \mathrm{To}$ a solution of compound 4 ( $28.6 \mathrm{mg}, 0.10 \mathrm{mmol}$ ) in $\mathrm{CH}_{2} \mathrm{Cl}_{2}$, was added $p$ toluene sulfonic acid $(28.5 \mathrm{mg}, 0.15 \mathrm{mmol})$ and the mixture was stirred for $3 \mathrm{~h}$ at room temperature $\left(34{ }^{\circ} \mathrm{C}\right)$. The solvent was removed under reduced pressure and the residue was taken in ethyl acetate and washed with $5 \% \mathrm{NaHCO}_{3}$ solution followed by brine, dried over anhydrous $\mathrm{Na}_{2} \mathrm{SO}_{4}$ and evaporated to get dark yellow oil. The crude product was purified using column chromatography over silica gel (80:20 ethyl acetate:petroleum ether) to obtain compound $\mathbf{1}$ as yellow solid (Yield: $22.0 \mathrm{mg}$, 90\%). ${ }^{1} \mathrm{H}$ NMR $\left(\mathrm{CD}_{3} \mathrm{OD}\right) \delta(\mathrm{ppm}): 3.18-3.27(\mathrm{~m}, 2 \mathrm{H}), 3.33-3.38(\mathrm{~m}, 2 \mathrm{H}), 3.53-3.63(\mathrm{~m}, 2 \mathrm{H}) ;{ }^{13} \mathrm{C}$ NMR $\left(\mathrm{CD}_{3} \mathrm{OD}\right) \delta(\mathrm{ppm}): 30.6,74.9 ;{ }^{77} \mathrm{Se} \mathrm{NMR}\left(\mathrm{CD}_{3} \mathrm{OD}\right) \delta(\mathrm{ppm}): 273$; Anal. Calcd. for $\mathrm{C}_{4} \mathrm{H}_{8} \mathrm{O}_{2} \mathrm{Se}_{2}: \mathrm{C}, 19.53$; H, 3.28. Found: C, 19.50; H, 3.27.

1.2.5. Synthesis of S5. A solution of compound S3 ((-)-1,4-di-O-tosyl-2,3-O-isopropylidene-L-threitol, $200 \mathrm{mg}, 0.42 \mathrm{mmol}$ ) in dry DMF (purged with $\mathrm{N}_{2}$ gas) was added dropwise via syringe for a period of $20 \mathrm{~min}$ to a freshly prepared solution of $\mathbf{S 2}(0.40 \mathrm{mmol})$ at $0{ }^{\circ} \mathrm{C}$. The ice-bath was removed and the mixture was stirred at room temperature $\left(34^{\circ} \mathrm{C}\right)$ under nitrogen atmosphere until all the starting material gets consumed. Water was added and the suspension was extracted with ethyl acetate $(3 \mathrm{x}$ $25 \mathrm{~mL}$ ). The combined organic layer was washed with brine, dried over anhydrous $\mathrm{Na}_{2} \mathrm{SO}_{4}$, and 
evaporated to get the crude product mixture. The desired compound was then purified using a column chromatography (silica-gel, 20:80 ethyl acetate:petroleum ether). Compound S5 was obtained as yellow oil in $88 \%$ yield $(186 \mathrm{mg}) .{ }^{1} \mathrm{H}$ NMR $\left(\mathrm{CDCl}_{3}\right) \delta(\mathrm{ppm}): 1.29(\mathrm{~s}, 3 \mathrm{H}), 1.36(\mathrm{~s}, 3 \mathrm{H}), 2.43(\mathrm{~s}, 3 \mathrm{H})$, $2.61(\mathrm{~d}, 2 \mathrm{H}, J=5.8 \mathrm{~Hz}), 3.77(\mathrm{~s}, 5 \mathrm{H}), 3.82-3.86(\mathrm{~m}, 1 \mathrm{H}), 3.90-3.95(\mathrm{~m}, 1 \mathrm{H}), 4.00-4.04(\mathrm{~m}, 1 \mathrm{H}), 4.12-$ $4.15(\mathrm{~m}, 1 \mathrm{H}), 6.82(\mathrm{~d}, 2 \mathrm{H}, J=8.4 \mathrm{~Hz}), 7.19(\mathrm{~d}, 2 \mathrm{H}, J=8.7 \mathrm{~Hz}), 7.33(\mathrm{~d}, 2 \mathrm{H}, J=8.2 \mathrm{~Hz}), 7.78(\mathrm{~d}, 2 \mathrm{H}$, $J=8.1 \mathrm{~Hz}) ;{ }^{13} \mathrm{C}$ NMR $\left(\mathrm{CDCl}_{3}\right) \delta(\mathrm{ppm}): 22.1,25.4,27.2,27.6,27.8,55.7,69.7,78.7,110.2,114.4$, 128.4, 130.3, 130.5, 131.1, 133.1, 145.5, 159.0; ${ }^{77} \mathrm{Se} \mathrm{NMR}\left(\mathrm{CDCl}_{3}\right) \delta(\mathrm{ppm}): 219$.

1.2.6. Synthesis of S6. To a solution of $\mathbf{S} 5(150 \mathrm{mg}, 0.30 \mathrm{mmol})$ in dry DMF, was added potassium thioacetate $(51 \mathrm{mg}, 0.45 \mathrm{mmol}$ ) and 18-crown-6 under nitrogen atmosphere and the mixture was stirred at room temperature $\left(34^{\circ} \mathrm{C}\right)$ for $24 \mathrm{~h}$. Ethyl acetate and water were added to the slurry and the organic layer was further washed with $5 \% \mathrm{NaHCO}_{3}$ solution, water and brine to obtain a yellow oil. The crude product was purified by using a column chromatography over silica gel to obtain compound S6 as pale-yellow oil (91 mg, 76\%). ${ }^{1} \mathrm{H}$ NMR $\left(\mathrm{CDCl}_{3}\right) \delta(\mathrm{ppm}): 1.38(\mathrm{~d}, 6 \mathrm{H}, J=6.4 \mathrm{~Hz}), 2.32(\mathrm{~s}, 3 \mathrm{H})$, 2.59-2.63 (m, 1H), 2.68-2.72 (m, 1H), 2.97-3.02 (m, 1H), 3.16-3.21 (m, 1H), $3.76(\mathrm{~s}, 3 \mathrm{H}), 3.79-3.82$ $(\mathrm{m}, 2 \mathrm{H}), 3.85-3.88(\mathrm{~m}, 1 \mathrm{H}), 6.79-6.82(\mathrm{~m}, 2 \mathrm{H}), 7.19-7.23(\mathrm{~m}, 2 \mathrm{H}) ;{ }^{77} \mathrm{Se} \mathrm{NMR}\left(\mathrm{CDCl}_{3}\right) \delta(\mathrm{ppm}): 223$.

1.2.7. Synthesis of $\mathbf{S} 7$. To a solution of compound $\mathbf{S} 6$ (50 mg, $0.12 \mathrm{mmol})$ in $\mathrm{EtOH}(1 \mathrm{~mL})$ was added a solution of $\mathrm{KOH}(10 \mathrm{mg}, 0.18 \mathrm{mmol})$ in water $(1 \mathrm{~mL})$. The mixture was stirred at $50{ }^{\circ} \mathrm{C}$ for $3 \mathrm{~h}$, and then the mixture was treated with aq. $\mathrm{KHSO}_{4}$ solution. The product was extracted with ethyl acetate $(3$ $x 25 \mathrm{~mL}$ ). The combined organic layer was washed with brine, dried over anhydrous $\mathrm{Na}_{2} \mathrm{SO}_{4}$, and evaporated to get the crude product. The desired compound $\mathbf{S 7}$ was obtained by purifying the products by column chromatography over silica-gel (25:75 ethyl acetate:petroleum ether). Compound S7 was obtained in $95 \%$ in $42.5 \mathrm{mg} .{ }^{13} \mathrm{C} \mathrm{NMR}\left(\mathrm{CDCl}_{3}\right) \delta$ (ppm): 25.8, 27.7, 27.8, 27.9, 30.1, 42.6, $55.7,79.8,80.5,109.7,114.4,130.5,131.3,158.9 ;{ }^{77}$ Se NMR $\left(\mathrm{CDCl}_{3}\right) \delta(\mathrm{ppm}): 222$.

1.2.8. Synthesis of 5 . To a solution of iodine $(32 \mathrm{mg}, 0.20 \mathrm{mmol})$ in $\mathrm{MeOH}(5 \mathrm{~mL})$ and $\mathrm{H}_{2} \mathrm{O}(1 \mathrm{~mL})$, a solution of $\mathbf{S 7}(50 \mathrm{mg}, 0.13 \mathrm{mmol})$ in THF $(5 \mathrm{~mL})$ was added dropwise, over a period of $15 \mathrm{~min}$. After additional $5 \mathrm{~min}$ of stirring at room temperature $\left(34^{\circ} \mathrm{C}\right)$, an aqueous $1 \mathrm{M}$ solution of hydrazine hydrate $(1 \mathrm{~mL})$ was added to the mixture to quench the excess iodine. The mixture was then extracted with ethyl acetate $3 \times 25 \mathrm{~mL}$ ). The combined organic layer was washed with water and brine, dried over anhydrous $\mathrm{Na}_{2} \mathrm{SO}_{4}$ and evaporated to give the crude product as yellow oil. Column chromatography over silica gel (20:80 ethyl acetate: petroleum ether) yielded 5 as pale-yellow oil (26 mg, 80\%). Compound 5 was gradually solidified to give yellow solid. ${ }^{1} \mathrm{H}$ NMR $\left(\mathrm{CDCl}_{3}\right) \delta(\mathrm{ppm}): 1.43(\mathrm{~s}, 6 \mathrm{H}), 3.11$ $3.20(\mathrm{~m}, 2 \mathrm{H}), 3.30-3.38(\mathrm{~m}, 2 \mathrm{H}), 3.51-3.57(\mathrm{~m}, 1 \mathrm{H}), 3.76-3.82(\mathrm{~m}, 1 \mathrm{H}) ;{ }^{13} \mathrm{C} \mathrm{NMR}\left(\mathrm{CDCl}_{3}\right) \delta(\mathrm{ppm})$ : 27.2, 30.1, 30.4, 38.2, 79.0, 79.3, 105.7; ${ }^{77} \mathrm{Se} \mathrm{NMR}\left(\mathrm{CDCl}_{3}\right) \delta(\mathrm{ppm})$ : 377; Anal. Calcd. for $\mathrm{C}_{7} \mathrm{H}_{12} \mathrm{O}_{2} \mathrm{SSe}: \mathrm{C}, 35.15 ; \mathrm{H}, 5.06$. Found: C, 35.95; $\mathrm{H}, 4.96$.

1.2.9. Synthesis of 2. To a solution of compound 5 (90 mg, $0.37 \mathrm{mmol})$ in $\mathrm{CH}_{2} \mathrm{Cl}_{2}$, was added $p$ toluene sulfonic acid (106 $\mathrm{mg}, 0.56 \mathrm{mmol}$ ) and the mixture was stirred for $3 \mathrm{~h}$ at room temperature (34 $\left.{ }^{\circ} \mathrm{C}\right)$. The solvent was removed under reduced pressure and the residue was taken in ethyl acetate and washed with $5 \% \mathrm{NaHCO}_{3}$ solution and brine, dried over anhydrous $\mathrm{Na}_{2} \mathrm{SO}_{4}$ and evaporated to 
get pale yellow oil. The impure compound was purified using column chromatography over silica gel (80:20 ethyl acetate:petroleum ether) to obtain 2 as pale-yellow crystalline solid $(67 \mathrm{mg}, 90 \%) .{ }^{1} \mathrm{H}$ $\operatorname{NMR}\left(\mathrm{CD}_{3} \mathrm{OD}\right) \delta(\mathrm{ppm}): 2.96-3.02(\mathrm{~m}, 1 \mathrm{H}), 3.10-3.11(\mathrm{~m}, 2 \mathrm{H}), 3.32-3.33(\mathrm{~m}, 1 \mathrm{H}), 3.39-3.45(\mathrm{~m}, 1 \mathrm{H})$, 3.58-3.63 (m, 1H); ${ }^{13} \mathrm{C}$ NMR $\left(\mathrm{CD}_{3} \mathrm{OD}\right) \delta(\mathrm{ppm}): 22.8,29.8,32.1,40.4 ;{ }^{77} \mathrm{Se} \mathrm{NMR}\left(\mathrm{CDCl}_{3}\right) \delta(\mathrm{ppm}): 377$; Anal. Calcd for $\mathrm{C}_{4} \mathrm{H}_{8} \mathrm{O}_{2} \mathrm{SSe}: \mathrm{C}, 24.13 ; \mathrm{H}, 4.05$. Found: $\mathrm{C}, 24.14 ; \mathrm{H}, 4.56$.

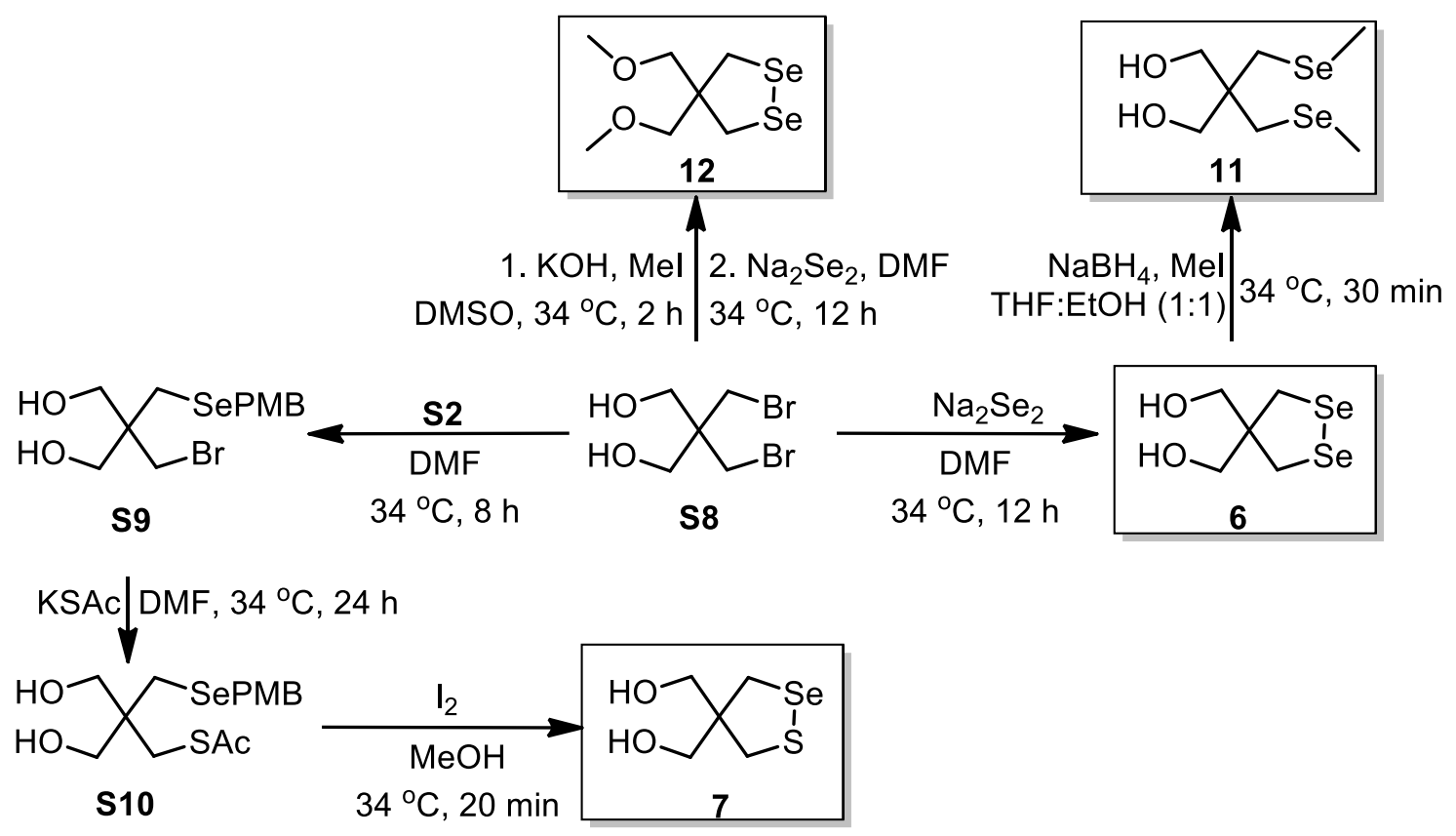

Scheme S2. Chemical synthesis of compounds 6,7,11 and 12.

1.2.10. Synthesis of 6 . The diselenide 6 was synthesized by following the literature procedure reported by Bergson with modifications. ${ }^{4 a, b}$ To a vigorously stirred suspension of powdered $\mathrm{NaOH}$ (160 mg, $4.0 \mathrm{mmol}$ ) and elemental selenium (316 mg, $4.0 \mathrm{mmol})$ in DMF, hydrazine hydrate $(50 \mathrm{mg}$, $1.0 \mathrm{mmol}$ ) was added dropwise under nitrogen atmosphere. After stirring the reaction mixture for additional $2 \mathrm{~h}$, a solution of compound S8 (262 $\mathrm{mg}, 1.10 \mathrm{mmol}$ ) dissolved in DMF was added dropwise and the mixture was stirred additional $12 \mathrm{~h}$ at room temperature $\left(34^{\circ} \mathrm{C}\right)$. The reaction was quenched by addition of dil. $\mathrm{HCl}$. Water was added and the mixture was extracted with ethyl acetate. The organic layer was washed with brine, dried over anhydrous $\mathrm{Na}_{2} \mathrm{SO}_{4}$ and evaporated to give the crude product as dark orange oil. The crude mixture was purified by column chromatography over silica gel (50:50 ethyl acetate:petroleum ether) to obtain compound 6 as dark orange solid (91 mg, $35 \%) .{ }^{1} \mathrm{H}$ NMR $\left(\mathrm{CD}_{3} \mathrm{OD}\right) \delta(\mathrm{ppm}): 3.24(\mathrm{~s}, 4 \mathrm{H}), 3.60(\mathrm{br} \mathrm{s}, 2 \mathrm{H}), 3.68(\mathrm{~s}, 4 \mathrm{H}) ;{ }^{13} \mathrm{C}$ NMR $\left(\mathrm{CD}_{3} \mathrm{OD}\right) \delta$ (ppm): 35.0, 59.4, 64.0; ${ }^{77}$ Se NMR $\left(\mathrm{CD}_{3} \mathrm{OD}\right) \delta(\mathrm{ppm}): 272$; Anal. Calcd. for $\mathrm{C}_{5} \mathrm{H}_{10} \mathrm{O}_{2} \mathrm{Se}_{2}: \mathrm{C}, 23.09 ; \mathrm{H}$, 3.88. Found: C, 23.59; $\mathrm{H}, 3.76$.

1.2.11. Synthesis of $\mathbf{S} 9$. To a solution of compound $\mathbf{S} 8(20 \mathrm{mg}, 0.076 \mathrm{mmol})$ in dry DMF (purged with $\mathrm{N}_{2}$ gas), a freshly prepared solution of $\mathbf{S} 2(0.038 \mathrm{mmol})$ was added dropwise via syringe for a period of $20 \mathrm{~min}$ at $0{ }^{\circ} \mathrm{C}$. The ice-bath was removed and the mixture was stirred at room temperature $\left(34{ }^{\circ} \mathrm{C}\right)$ under nitrogen atmosphere for $8 \mathrm{~h}$. Water was added and the suspension was extracted with ethyl 
acetate $(3 \times 25 \mathrm{~mL})$. The combined organic layer was washed with brine, dried over anhydrous $\mathrm{Na}_{2} \mathrm{SO}_{4}$, and evaporated to get the crude product. The desired product was then purified by column chromatography over silica-gel (50:50 EtOAc:petroleum ether) to obtain S9 as pale yellow solid (11 mg, 38\%). ${ }^{1} \mathrm{H}$ NMR $\left(\mathrm{CDCl}_{3}\right) \delta(\mathrm{ppm}): 2.49(\mathrm{~s}, 2 \mathrm{H}), 2.60(\mathrm{~s}, 2 \mathrm{H}), 3.51(\mathrm{~s}, 2 \mathrm{H}), 3.62(\mathrm{~s}, 4 \mathrm{H}), 3.78(\mathrm{~s}, 3 \mathrm{H})$, $3.79(\mathrm{~s}, 2 \mathrm{H}), 6.83(\mathrm{~d}, 2 \mathrm{H}, J=8.7 \mathrm{~Hz}), 7.23(\mathrm{~d}, 2 \mathrm{H}, J=8.6 \mathrm{~Hz}) ;{ }^{77} \mathrm{Se} \mathrm{NMR}\left(\mathrm{CDCl}_{3}\right) \delta(\mathrm{ppm}): 180$; ESIMS (m/z) calculated for $\mathrm{C}_{13} \mathrm{H}_{19} \mathrm{BrO}_{3} \mathrm{Se}[\mathrm{M}+\mathrm{Na}]^{+}: 404.9580$, found: 404.9620 .

1.2.12. Synthesis of $\mathbf{S} 10$. To a solution of compound $\mathbf{S} 9(10 \mathrm{mg}, 0.02 \mathrm{mmol})$ in dry DMF, was added potassium thioacetate $(4.5 \mathrm{mg}, 0.03 \mathrm{mmol})$ under nitrogen atmosphere and the mixture was stirred at room temperature $\left(34^{\circ} \mathrm{C}\right)$ for $24 \mathrm{~h}$. The mixture was then treated with ethyl acetate and water. The organic layer was further washed with $5 \% \mathrm{NaHCO}_{3}$ solution, water and brine to obtain yellow oil. The crude product was purified by column chromatography over silica gel (50:50 ethyl acetate-petroleum ether) to obtain $\mathbf{S 1 0}$ as pale-yellow oil, which solidified on standing to give yellow solid (5.9 $\mathrm{mg}, 60 \%)$. ${ }^{1} \mathrm{H}$ NMR $\left(\mathrm{CDCl}_{3}\right) \delta(\mathrm{ppm}): 2.40(\mathrm{~s}, 3 \mathrm{H}), 2.50(\mathrm{~s}, 2 \mathrm{H}), 3.08(\mathrm{~s}, 2 \mathrm{H}), 3.49-3.50(\mathrm{~m}, 4 \mathrm{H}), 3.77(\mathrm{~s}, 2 \mathrm{H}), 3.81$ $(\mathrm{s}, 5 \mathrm{H}), 6.84-6.86(\mathrm{~m}, 2 \mathrm{H}), 7.23-7.25(\mathrm{~m}, 2 \mathrm{H}) ;{ }^{77}$ Se NMR $\left(\mathrm{CDCl}_{3}\right) \delta(\mathrm{ppm}): 181 ;$ ESI-MS $(\mathrm{m} / \mathrm{z})$ calculated for $\mathrm{C}_{15} \mathrm{H}_{22} \mathrm{O}_{4} \mathrm{SSe}[\mathrm{M}+\mathrm{Na}]^{+}: 401.0302$, found: 401.0736 .

1.2.13. Synthesis of 7. To a solution of iodine $(5.0 \mathrm{mg}, 0.01 \mathrm{mmol})$ in $\mathrm{MeOH}(5 \mathrm{~mL})$ and $\mathrm{H}_{2} \mathrm{O}(1 \mathrm{~mL})$, was added a solution of $\mathbf{S} 10(5.0 \mathrm{mg}, 0.02 \mathrm{mmol})$ in $\mathrm{MeOH}(5 \mathrm{~mL})$ dropwise, over a period of $15 \mathrm{~min}$ at room temperature $\left(34{ }^{\circ} \mathrm{C}\right)$. After stirring for additional $5 \mathrm{~min}$ at room temperature, a $1 \mathrm{M}$ aqueous solution of hydrazine hydrate $(1 \mathrm{~mL})$ was added to the mixture to quench the excess iodine. The mixture was then extracted with ethyl acetate $(3 \times 25 \mathrm{~mL})$. The combined organic layer was washed with water and brine, dried over anhydrous $\mathrm{Na}_{2} \mathrm{SO}_{4}$ and evaporated to give the crude product as yellow oil. Column chromatography over silica gel (50:50 ethyl acetate-petroleum ether) yielded the selenenyl sulphide 7 as pale-yellow oil, which solidified on standing to give yellow solid $(1.3 \mathrm{mg}$, 46\%). ${ }^{1} \mathrm{H}$ NMR ( $\left.\mathrm{CD}_{3} \mathrm{OD}\right) \delta(\mathrm{ppm}): 2.35$ (s, 2H), 2.96 (s, 2H), $3.42(\mathrm{~s}, 4 \mathrm{H}) ;{ }^{77}$ Se NMR $\left(\mathrm{CD}_{3} \mathrm{OD}\right) \delta$ (ppm): 340. Anal. Calcd. for $\mathrm{C}_{5} \mathrm{H}_{10} \mathrm{O}_{2} \mathrm{SSe}$ : C, 28.17; H, 4.73. Found: C, 28.30; H, 4.76.

1.2.14. Synthesis of 11. To a solution of $7(5.0 \mathrm{mg}, 0.02 \mathrm{mmol})$ in THF:EtOH $(1: 1 \mathrm{v} / \mathrm{v}, 1 \mathrm{~mL})$ was added $\mathrm{Mel}(5.4 \mathrm{mg}, 0.04 \mathrm{mmol})$ followed by $\mathrm{NaBH}_{4}(1.4 \mathrm{mg}, 0.04 \mathrm{mmol})$ at $0{ }^{\circ} \mathrm{C}$. The mixture was then stirred at room temperature $\left(34^{\circ} \mathrm{C}\right)$ for $30 \mathrm{~min}$ and quenched by addition of dil. $\mathrm{HCl}$. Water was added and the mixture was extracted with ethyl acetate $(3 \times 25 \mathrm{~mL})$. The combined organic layers were washed with brine, dried over anhydrous $\mathrm{Na}_{2} \mathrm{SO}_{4}$ and evaporated to obtain yellow oil. Column chromatography over silica gel (50:50 EtOAc:petroleum ether) yielded compound $\mathbf{1 1}$ as pale yellow oil (5.3 mg, 95\%). ${ }^{1} \mathrm{H}$ NMR $\left(\mathrm{CDCl}_{3}\right) \delta(\mathrm{ppm}): 2.05$ (s, 6H), $2.73(\mathrm{~s}, 4 \mathrm{H}), 3.71(\mathrm{~s}, 4 \mathrm{H}) ;{ }^{13} \mathrm{C} \mathrm{NMR}\left(\mathrm{CDCl}_{3}\right) \delta$ (ppm): 6.7, 31.0, 45.0, 67.7; ${ }^{77} \mathrm{Se} \mathrm{NMR}\left(\mathrm{CDCl}_{3}\right) \delta$ (ppm): 8; Anal. Calcd. for $\mathrm{C}_{7} \mathrm{H}_{16} \mathrm{O}_{2} \mathrm{Se}_{2}$ : C, 28.98; $\mathrm{H}$, 5.56. Found: C, 28.83; H, 5.51.

1.2.15. Synthesis of 12. Step 1. Potassium hydroxide $(500 \mathrm{mg}, 8.0 \mathrm{mmol})$ was added to DMSO (1 $\mathrm{mL}$ ) in a round bottomed flask. An excess amount of Mel was added to the suspension, followed by the immediate addition of compound $\mathbf{S 8}(262 \mathrm{mg}, 1 \mathrm{mmol})$. After stirring the reaction mixture for $2 \mathrm{~h}$ at room temperature $\left(34{ }^{\circ} \mathrm{C}\right)$, the solution was acidified with dil. $\mathrm{HCl}$. The compound was extracted with 
chloroform three times and the solvents were removed under reduced pressure to give the crude dimethylated product (246 mg, 85\%) as colourless oil. It was used for the subsequent step without further purification.

Step 2. To a vigorously stirred suspension of powdered $\mathrm{NaOH}(88 \mathrm{mg}, 2.2 \mathrm{mmol}$ ) and elemental selenium (174 mg, $2.2 \mathrm{mmol}$ ) in DMF was added hydrazine hydrate $(28 \mathrm{mg}, 0.55 \mathrm{mmol}$ ) dropwise under nitrogen atmosphere. After stirring the reaction mixture for additional $2 \mathrm{~h}$, the di-methylated compound obtained from Step $1(160 \mathrm{mg}, 0.55 \mathrm{mmol}$ ) dissolved in DMF was added dropwise. The reaction mixture was stirred for $12 \mathrm{~h}$ at room temperature and the reaction was quenched by addition of dil. $\mathrm{HCl}$. Water was added and the mixture was extracted with ethyl acetate. The organic layers were combined and washed with brine, dried over anhydrous $\mathrm{Na}_{2} \mathrm{SO}_{4}$ and evaporated to give the crude product as dark orange oil. The desired product was purified by column chromatography over silica gel (5:95 ethyl acetate:petroleum ether) to obtain compound 12 as dark orange oil (103 $\mathrm{mg}$, $65 \%) .{ }^{1} \mathrm{H}$ NMR $\left(\mathrm{CDCl}_{3}\right) \delta(\mathrm{ppm}): 3.24(\mathrm{~s}, 4 \mathrm{H}), 3.37$ (s, 6H), 3.45 (s, 4H); ${ }^{13} \mathrm{C} \mathrm{NMR}\left(\mathrm{CDCl}_{3}\right) \delta(\mathrm{ppm})$ : 36.4, 58.4, 59.9, 74.7; ${ }^{77} \mathrm{Se} \mathrm{NMR}\left(\mathrm{CDCl}_{3}\right) \delta$ (ppm):280; Anal. Calcd for $\mathrm{C}_{7} \mathrm{H}_{14} \mathrm{O}_{2} \mathrm{Se}_{2}$ : C, 29.18; $\mathrm{H}, 4.90$. Found: C, 29.59; H, 4.37.
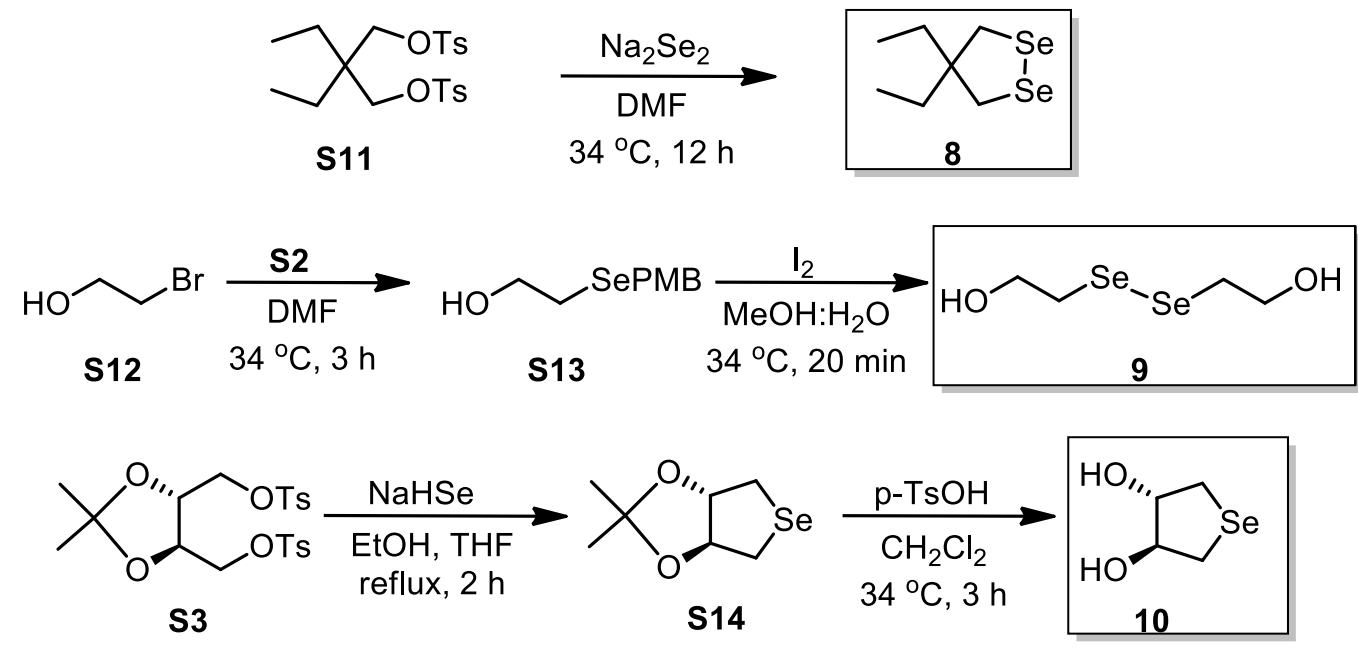

Scheme S3. Chemical synthesis of compounds 8-10.

1.2.16. Synthesis of 8. To a vigorously stirred suspension of powdered $\mathrm{NaOH}$ (185 mg, $4.6 \mathrm{mmol}$ ) and elemental selenium (366 mg, $4.6 \mathrm{mmol}$ ) in DMF was added hydrazine hydrate (58 mg, 1.16 mmol) dropwise under nitrogen atmosphere. After stirring for additional $2 \mathrm{~h}$, a solution of S11 (500 $\mathrm{mg}, 1.16 \mathrm{mmol}$ ) dissolved in DMF was added dropwise and the reaction was stirred addition for $12 \mathrm{~h}$. The reaction was quenched by addition of dil. $\mathrm{HCl}$. Water was added and the mixture was extracted with ethyl acetate. The organic layer was washed with brine, dried over anhydrous $\mathrm{Na}_{2} \mathrm{SO}_{4}$ and evaporated to give the crude product as dark orange oil. The product was purified by column chromatography over silica gel (5:95 ethyl acetate:petroleum ether) to obtain compound $\mathbf{8}$ as dark orange oil (203 mg, 70\%). ${ }^{1} \mathrm{H}$ NMR $\left(\mathrm{CDCl}_{3}\right) \delta(\mathrm{ppm})$ : 0.90-0.94 (t, 6H), 1.58-1.62 (q, 4H), $3.12(\mathrm{~s}, 4 \mathrm{H})$; ${ }^{13} \mathrm{C}$ NMR $\left(\mathrm{CDCl}_{3}\right) \delta(\mathrm{ppm}): 9.5,27.9,30.1,41.4 ;{ }^{77} \mathrm{Se} \mathrm{NMR}\left(\mathrm{CDCl}_{3}\right) \delta(\mathrm{ppm}): 270$; Anal. Calcd for $\mathrm{C}_{7} \mathrm{H}_{14} \mathrm{Se}_{2}$ : C, 32.83; $\mathrm{H}, 5.51$. Found: C, 33.05; $\mathrm{H}, 5.53$. 
1.2.17. Synthesis of $\mathbf{S} 13$. A solution of compound $\mathbf{S} 12(125 \mathrm{mg}, 1.0 \mathrm{mmol})$ in dry DMF (purged with nitrogen gas) was added dropwise via syringe for a period of $20 \mathrm{~min}$ to a freshly prepared solution of S2 $(1.2 \mathrm{mmol})$ at $0{ }^{\circ} \mathrm{C}$. The ice-bath was removed and the mixture was stirred at room temperature $\left(34{ }^{\circ} \mathrm{C}\right)$ under nitrogen atmosphere for $3 \mathrm{~h}$. Water was added and the suspension was extracted with ethyl acetate $(3 \times 25 \mathrm{~mL})$. The combined organic layer was washed with brine, dried over anhydrous $\mathrm{Na}_{2} \mathrm{SO}_{4}$, and evaporated to get the crude product, which was further purified by column chromatography over silica-gel (40:60 ethyl acetate:petroleum ether) to obtain the desired compound S13 as pale yellow oil (203 mg, 83\%). ${ }^{1} \mathrm{H}$ NMR $\left(\mathrm{CDCl}_{3}\right) \delta(\mathrm{ppm}): 2.38(\mathrm{br} \mathrm{s}, 1 \mathrm{H}), 2.67-2.70(\mathrm{t}, 2 \mathrm{H})$, 3.68-3.71 (t, $2 \mathrm{H}), 3.77$ (s, 2H), $3.80(\mathrm{~s}, 3 \mathrm{H}), 6.83-6.86(\mathrm{~d}, 2 \mathrm{H}, J=8.4 \mathrm{~Hz}), 7.21-7.23(\mathrm{~d}, 2 \mathrm{H}, J=8.7$ $\mathrm{Hz}) ;{ }^{13} \mathrm{C} \mathrm{NMR}\left(\mathrm{CDCl}_{3}\right) \delta$ (ppm): 26.9, 27.8, 55.7, 61.6, 114.5, 130.4, 131.4, 159.0; ${ }^{77} \mathrm{Se} \mathrm{NMR}\left(\mathrm{CDCl}_{3}\right)$ $\delta$ (ppm): 196.

1.2.18. Synthesis of 9 . lodine ( $124 \mathrm{mg}, 0.49 \mathrm{mmol}$ ) was added to a solution of $\mathbf{S} 13$ ( $80 \mathrm{mg}, 0.32$ $\mathrm{mmol})$ in $\mathrm{MeOH}(5 \mathrm{~mL})$ and $\mathrm{H}_{2} \mathrm{O}(1 \mathrm{~mL})$. After stirring the mixture for 20 min at room temperature (34 $\left.{ }^{\circ} \mathrm{C}\right)$, a $1 \mathrm{M}$ aqueous solution of hydrazine hydrate $(1 \mathrm{~mL})$ was added to the mixture to quench the excess iodine. The mixture was then extracted with ethyl acetate $(3 \times 25 \mathrm{~mL})$. The combined organic layer was washed with water and brine, dried over anhydrous $\mathrm{Na}_{2} \mathrm{SO}_{4}$ and evaporated to yield the crude product as yellow oil. Column chromatography over silica gel (80:20 ethyl acetate:petroleum ether) yielded the desired compound 9 as pale yellow oil (51 mg, 80\%). ${ }^{1} \mathrm{H} \mathrm{NMR}\left(\mathrm{CDCl}_{3}\right) \delta(\mathrm{ppm})$ : 3.03-3.09 (m, 4H), 3.78-3.84 (m, 4H); ${ }^{13} \mathrm{C} \mathrm{NMR}\left(\mathrm{CDCl}_{3}\right) \delta(\mathrm{ppm}): 32.1,62.1 ;{ }^{77} \mathrm{Se} \mathrm{NMR}\left(\mathrm{CDCl}_{3}\right) \delta$ (ppm): 275; Anal. Calcd. for $\mathrm{C}_{4} \mathrm{H}_{10} \mathrm{O}_{2} \mathrm{Se}_{2}$ : C, 19.37; H, 4.06. Found: C, 19.41; $\mathrm{H}, 4.03$.

1.2.19. Synthesis of 10 . The cylic monoselenide 10 was synthesized by following the procedure described by Iwaoka and co-workers with minor modifications. ${ }^{3 a}$ Elemental selenium (10 mg, 0.13 mmol) and $\mathrm{NaBH}_{4}(3.1 \mathrm{mg}, 0.08 \mathrm{mmol})$ were placed in a two-necked round-bottomed flask under nitrogen atmosphere. The solution turned wine-red color when $\mathrm{EtOH}(200 \mu \mathrm{L})$ was added to the above mixture. Compound $\mathbf{S} 3(20 \mathrm{mg}, 0.04 \mathrm{mmol})$ in dry THF $(1 \mathrm{~mL})$ was added dropwise and the reaction mixture was heated at reflux for $2 \mathrm{~h}$. The mixture was then allowed to reach room temperature, following which water was added and extracted with ethyl acetate. The combined organic layers were collected, washed with brine, dried over anhydrous $\mathrm{Na}_{2} \mathrm{SO}_{4}$, and evaporated to obtain yellow oil. Column chromatography of the crude product mixture over silica gel (20:80 EtOAc:petroleum ether) afforded compound $\mathbf{S 1 4}$ as pale-yellow gummy solid (2.4 $\mathrm{mg}, 28 \%$ ). All the NMR data are in agreement with the reported values. Anal. Calcd. for $\mathrm{C}_{4} \mathrm{H}_{8} \mathrm{O}_{2} \mathrm{Se}: \mathrm{C}, 28.76 ; \mathrm{H}, 4.83$. Found: C, 28.68; $\mathrm{H}, 4.85$.

Compound $\mathrm{S} 14$ (2.4 mg, $0.01 \mathrm{mmol}$ ) was dissolved in $\mathrm{CH}_{2} \mathrm{Cl}_{2}(1 \mathrm{~mL})$ and p-toluene sulfonic acid (3.3 $\mathrm{mg}, 0.02 \mathrm{mmol})$ was added. The reaction mixture was stirred at room temperature $\left(34{ }^{\circ} \mathrm{C}\right)$ for $3 \mathrm{~h}$, following which the solvent was removed under reduced pressure. Column chromatography of the crude product mixture over silica gel (80:20 EtOAc:petroleum ether) afforded compound $\mathbf{1 0}$ as a white solid (1.7 mg, 88\%). ${ }^{1} \mathrm{H}$ NMR ( $\left.\mathrm{CD}_{3} \mathrm{OD}\right) \delta$ (ppm): 2.80-2.83 (t, 2H), 3.09-3.13 (dd, 2H); 4.21-4.22 (br m, $2 \mathrm{H}){ }^{13} \mathrm{C}$ NMR $\left(\mathrm{CD}_{3} \mathrm{OD}\right) \delta(\mathrm{ppm}): 26.8,79.0 ;{ }^{77} \mathrm{Se} \mathrm{NMR}\left(\mathrm{CD}_{3} \mathrm{OD}\right) \delta(\mathrm{ppm}): 78$. 


\section{Protocols for cellular experiments}

2.1. Methemoglobin level: Washed RBCs ( $5 \%$ hematocrit) were independently treated with $t$ - $\mathrm{BuOOH}$ $(100 \mu \mathrm{M})$ in the presence and absence of co-treated organoselenium compounds (10 $\mu \mathrm{M})$ for $30 \mathrm{~min}$ at $37{ }^{\circ} \mathrm{C}$. After incubation, RBCs were lysed with $2 \mathrm{mM}$ phosphate buffered saline (PBS) $\mathrm{pH} 7.4$ containing $1 \%$ Triton X-100 $(1: 1, \mathrm{v} / \mathrm{v})$ and the absorbance of hemolysate was recorded at $400 \mathrm{~nm}$ to $700 \mathrm{~nm}$ to determine the oxidation of hemoglobin using UV-visible spectrophotometer. ${ }^{5 \mathrm{a}}$

2.2. Evaluation of $t$-BuOOH-induced cytotoxicity: $\mathrm{RBCs}$ ( $1 \%$ hematocrit) were either left untreated or treated with $t \mathrm{BuOOH}(100 \mu \mathrm{M})$, in the presence or absence of organoselenium compounds $(10 \mu \mathrm{M})$ for $30 \mathrm{~min}$ at $37^{\circ} \mathrm{C}$. The cells were then loaded with $1 \mu \mathrm{M}$ of calcein-AM for $30 \mathrm{~min}$ or $5 \mu \mathrm{M}$ of DCFHDA for $15 \mathrm{~min}$ for determination of cell viability and oxidant levels respectively. The cells were then washed with ringer solution and the fluorescence was analyzed using flow cytometry (BD FACS Celesta). The mean fluorescence intensity values for all the experiments were represented as percentage of cell viability and fold change with respect to the untreated cells. ${ }^{5 b}$

\section{Characterization and cellular studies}

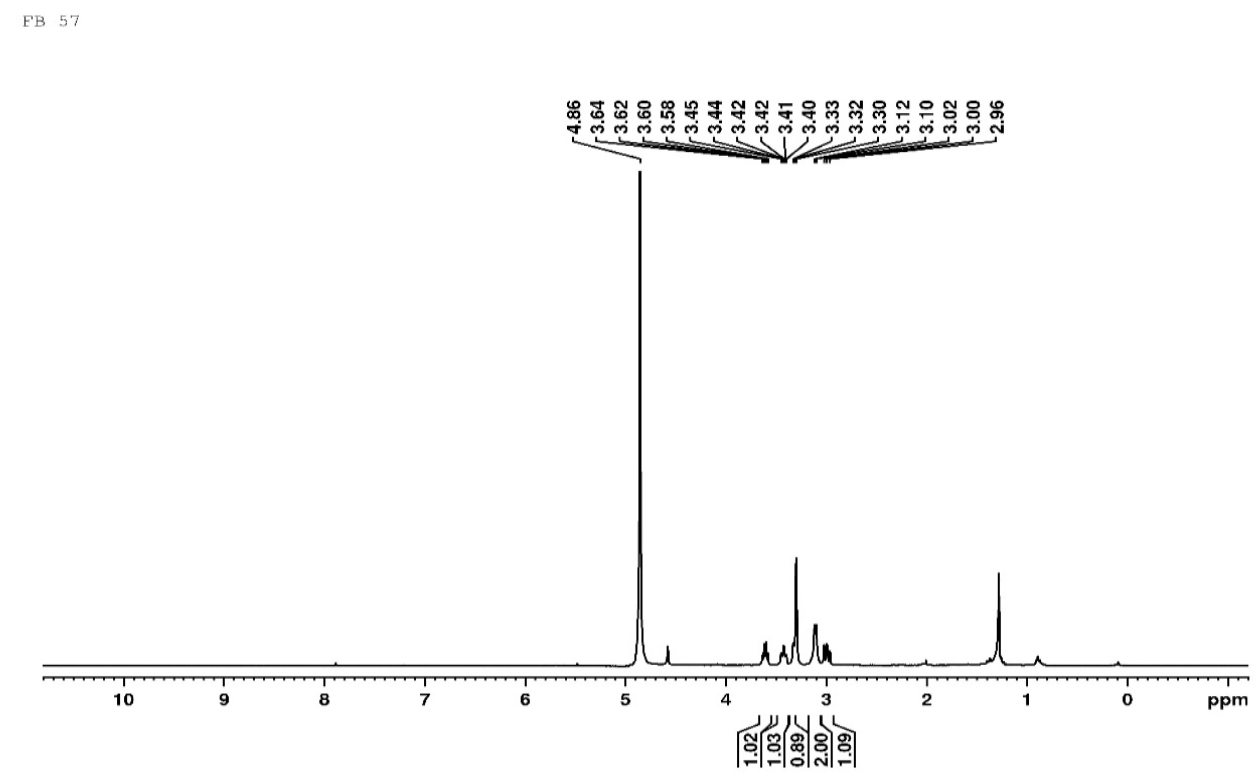

Figure S1. ${ }^{1} \mathrm{H}$ NMR spectrum of compound 2 in $\mathrm{CD}_{3} \mathrm{OD}$. 


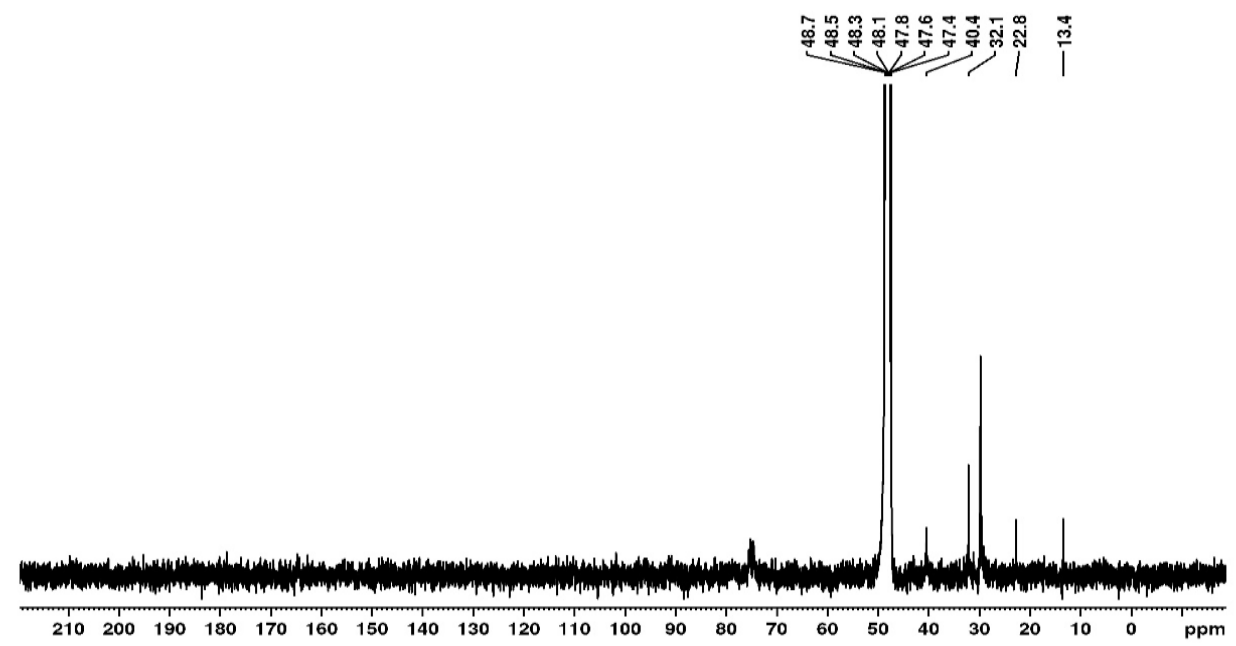

Figure S2. ${ }^{13} \mathrm{C}$ NMR spectrum of compound 2 in $\mathrm{CD}_{3} \mathrm{OD}$.

$$
\text { 昼 }
$$

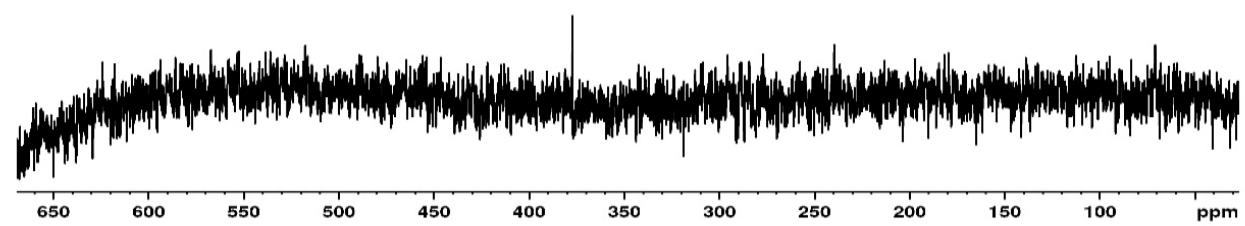

Figure S3. ${ }^{77}$ Se NMR spectrum of compound 2 in $\mathrm{CD}_{3} \mathrm{OD}$. 


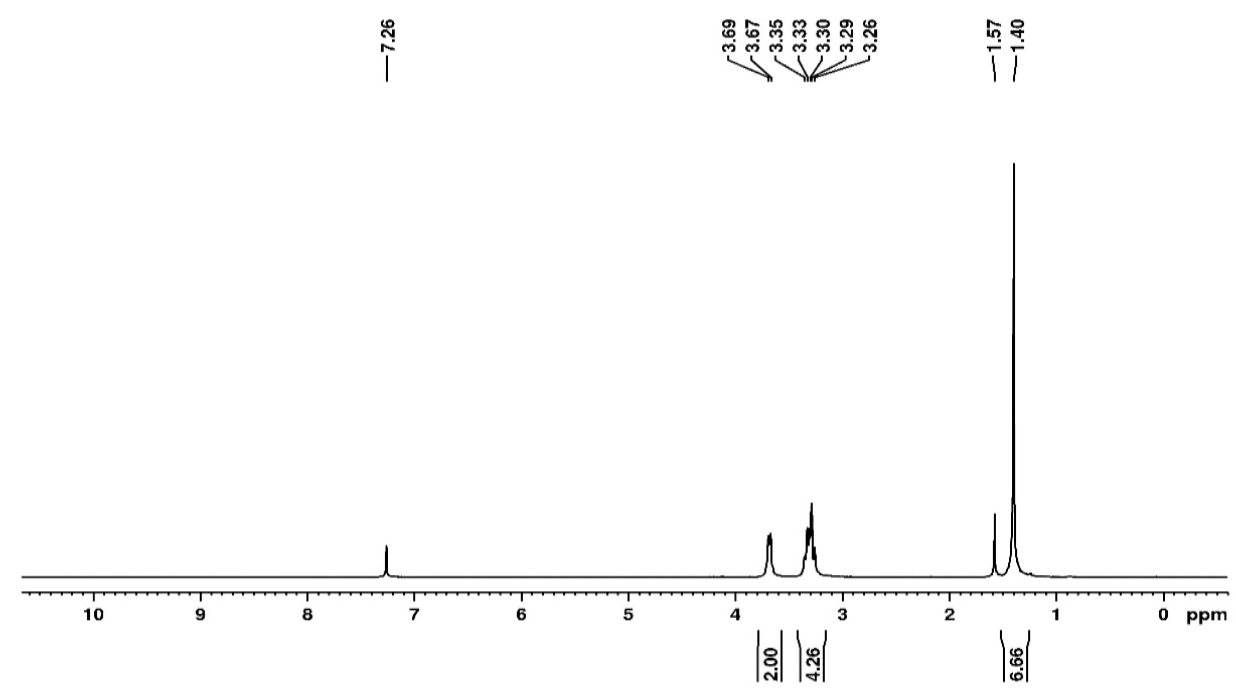

Figure S4. ${ }^{1} \mathrm{H}$ NMR spectrum of compound $\mathbf{4}$ in $\mathrm{CDCl}_{3}$.

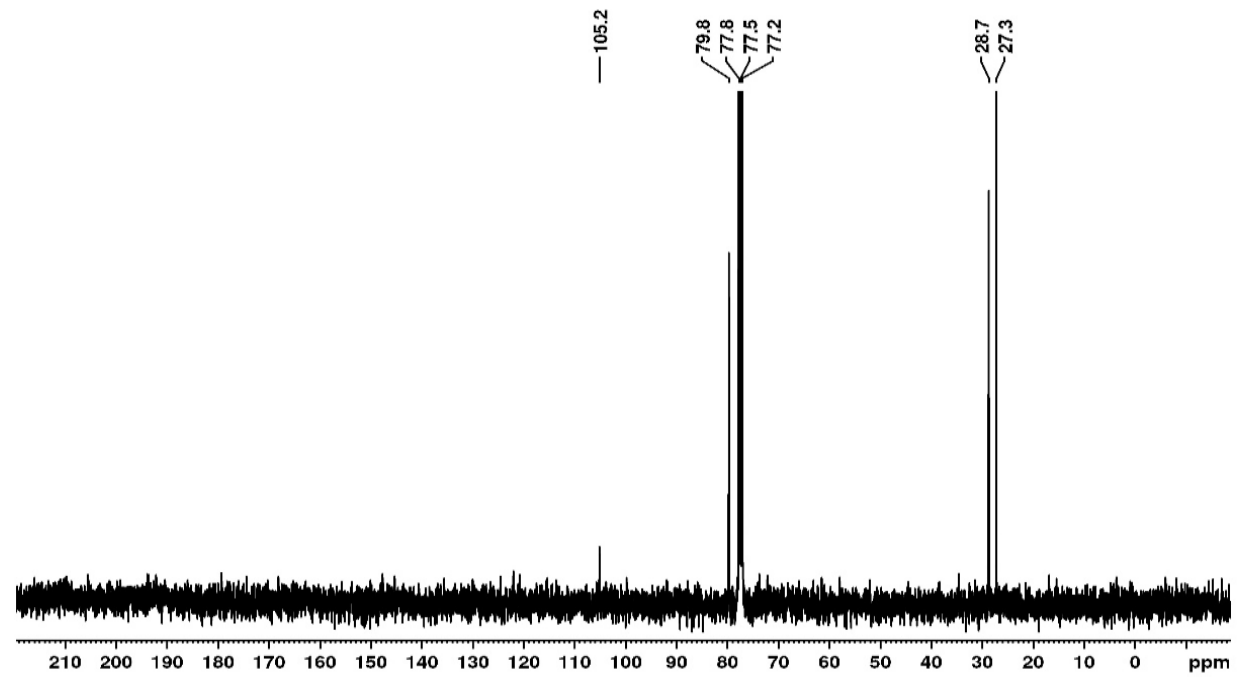

Figure S5. ${ }^{13} \mathrm{C}$ NMR spectrum of compound 4 in $\mathrm{CDCl}_{3}$. 


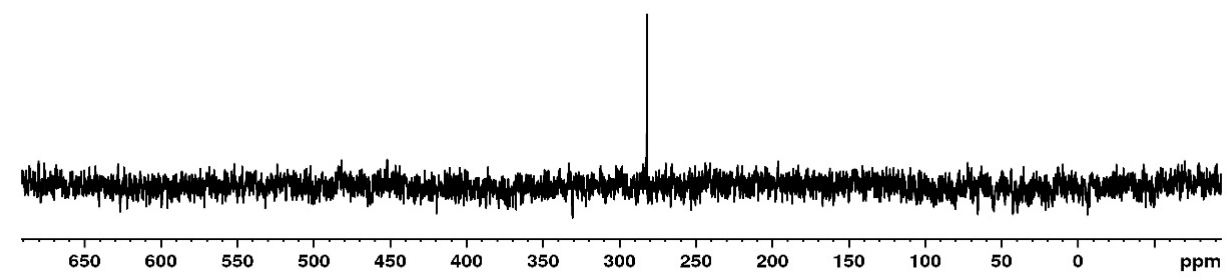

Figure S6. ${ }^{77}$ Se NMR spectrum of compound 4 in $\mathrm{CDCl}_{3}$.

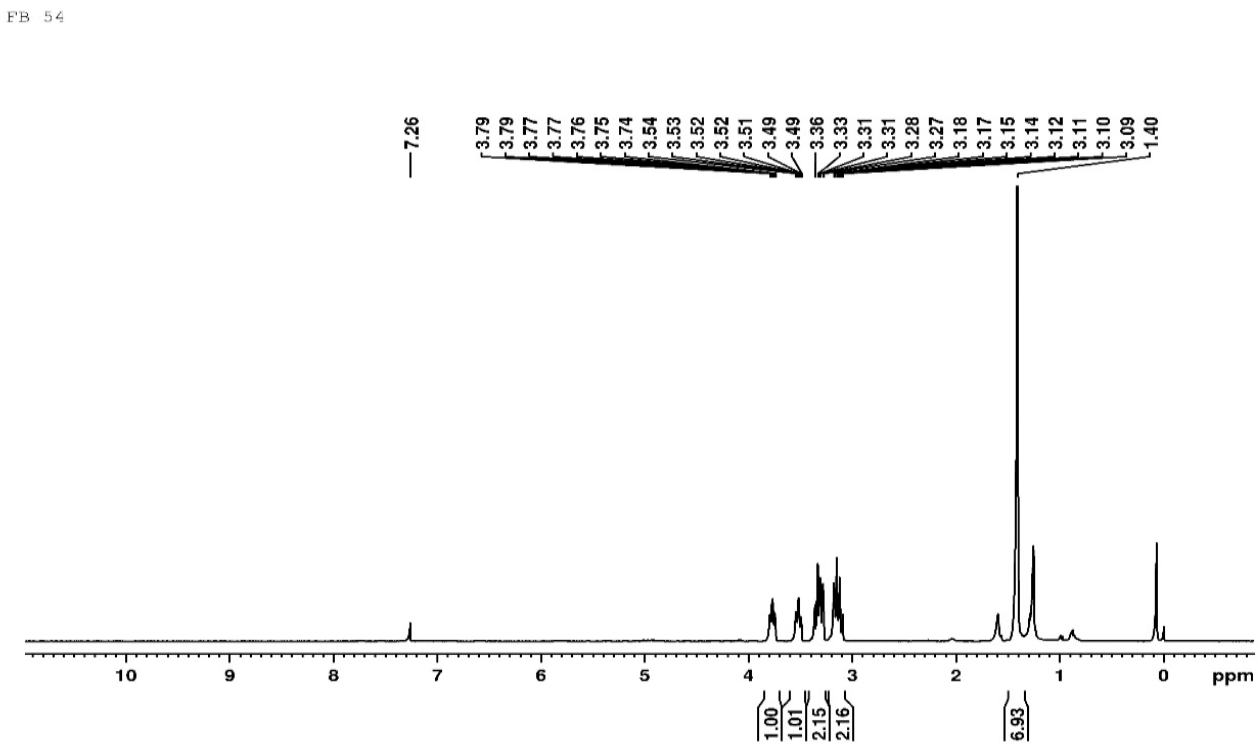

Figure S7. ${ }^{1} \mathrm{H}$ NMR spectrum of compound $\mathbf{5}$ in $\mathrm{CDCl}_{3}$. 


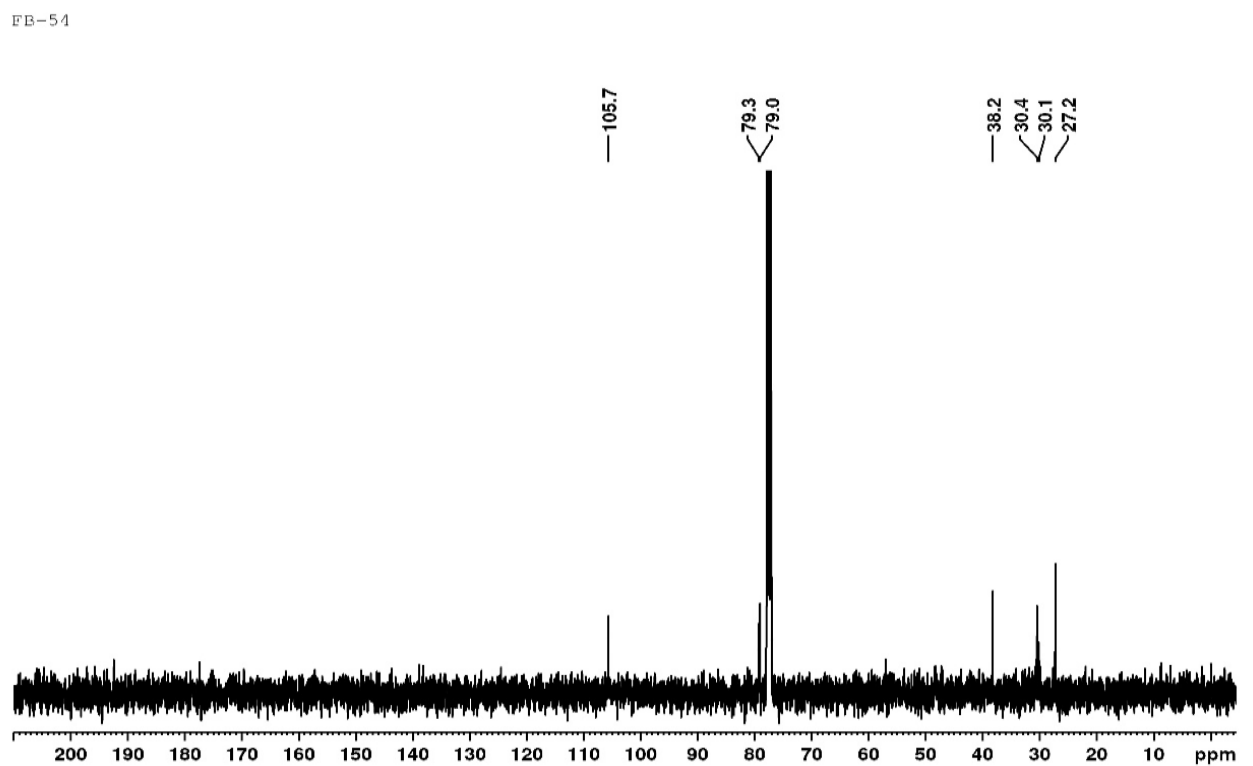

Figure S8. ${ }^{13} \mathrm{C}$ NMR spectrum of compound 5 in $\mathrm{CDCl}_{3}$.

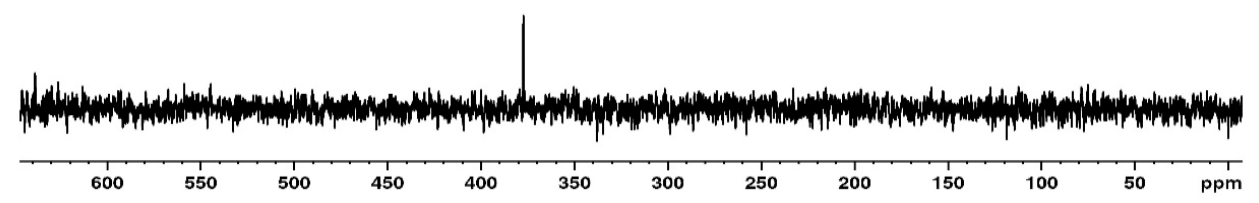

Figure S9. ${ }^{77}$ Se NMR spectrum of compound 5 in $\mathrm{CDCl}_{3}$. 

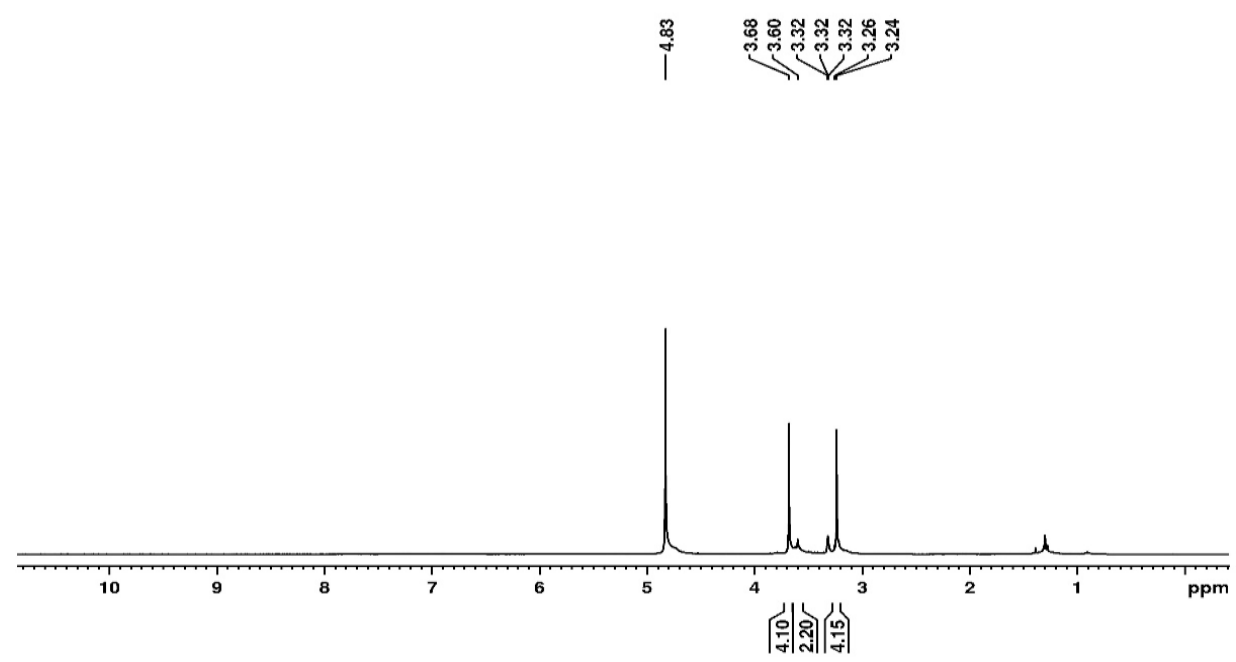

Figure S10. ${ }^{1} \mathrm{H}$ NMR spectrum of compound 6 in $\mathrm{CD}_{3} \mathrm{OD}$.

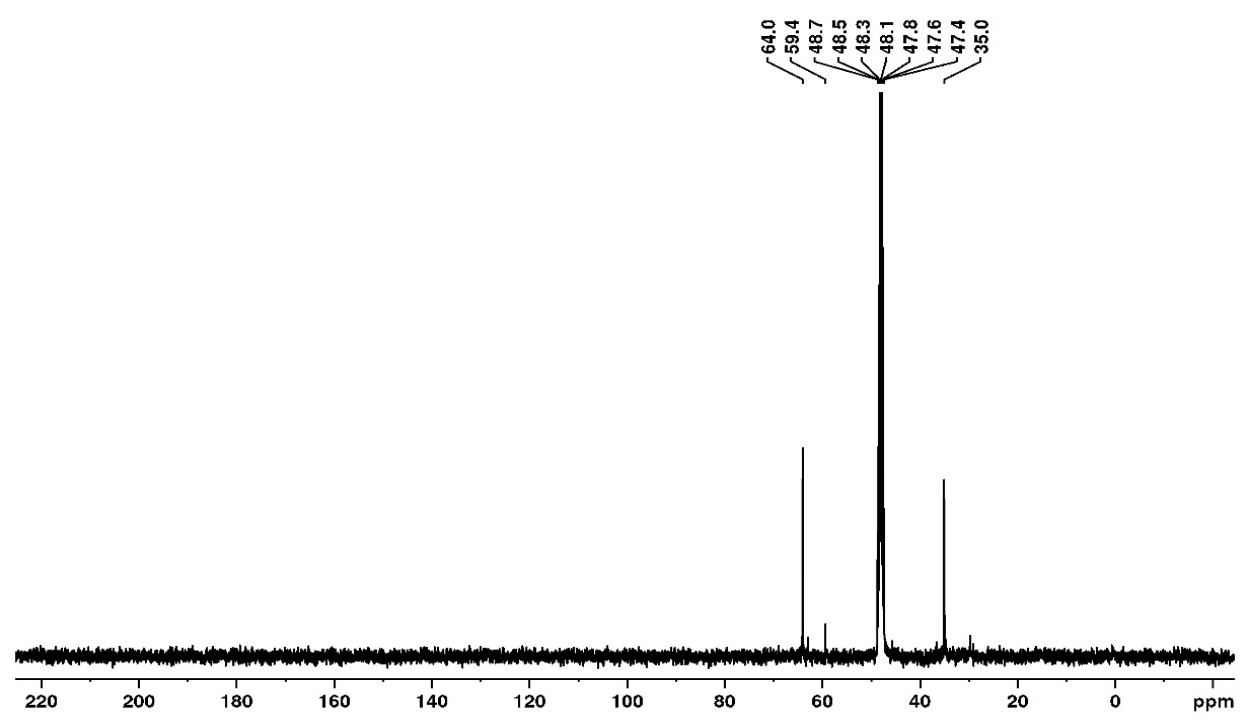

Figure S11. ${ }^{13} \mathrm{C}$ NMR spectrum of compound 6 in $\mathrm{CD}_{3} \mathrm{OD}$. 


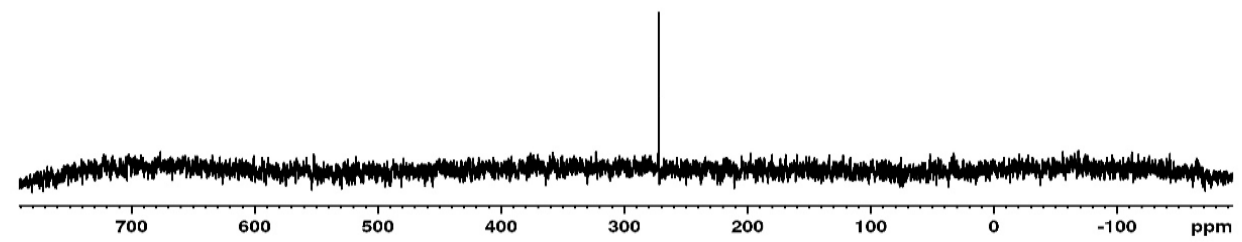

Figure S12. ${ }^{77}$ Se NMR spectrum of compound 6 in $\mathrm{CD}_{3} \mathrm{OD}$.

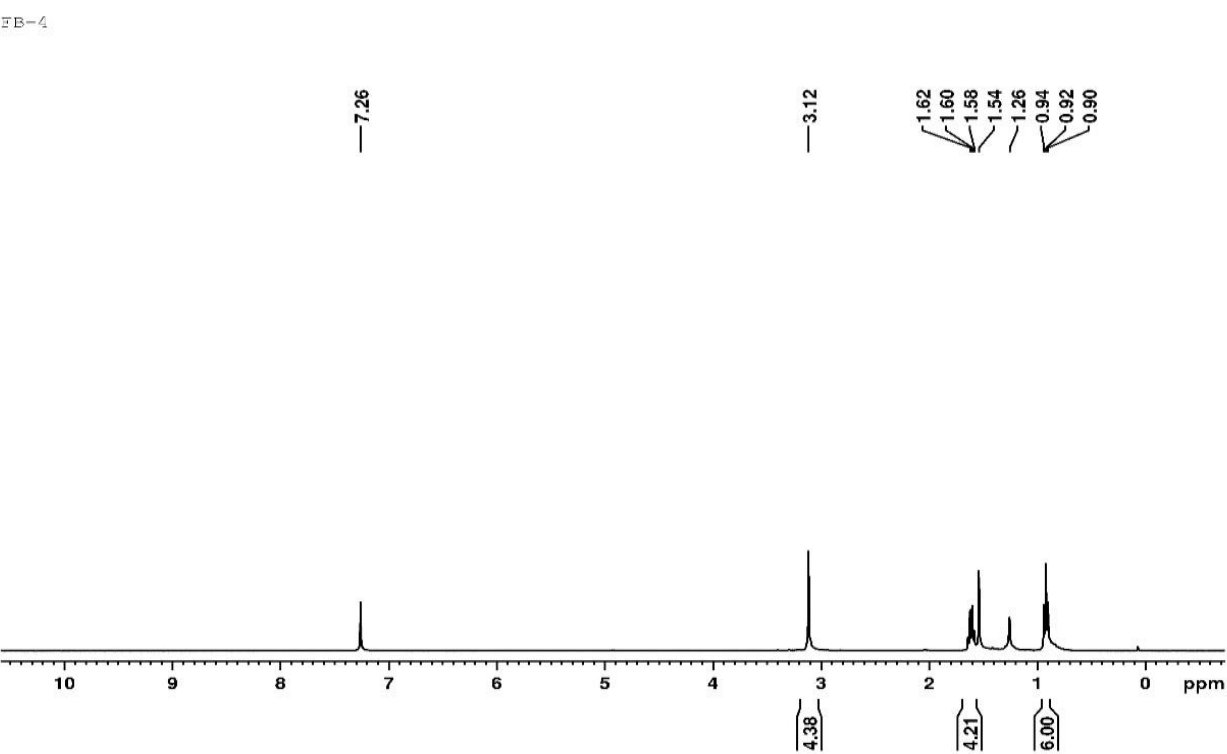

Figure S13. ${ }^{1} \mathrm{H}$ NMR spectrum of compound 8 in $\mathrm{CDCl}_{3}$. 


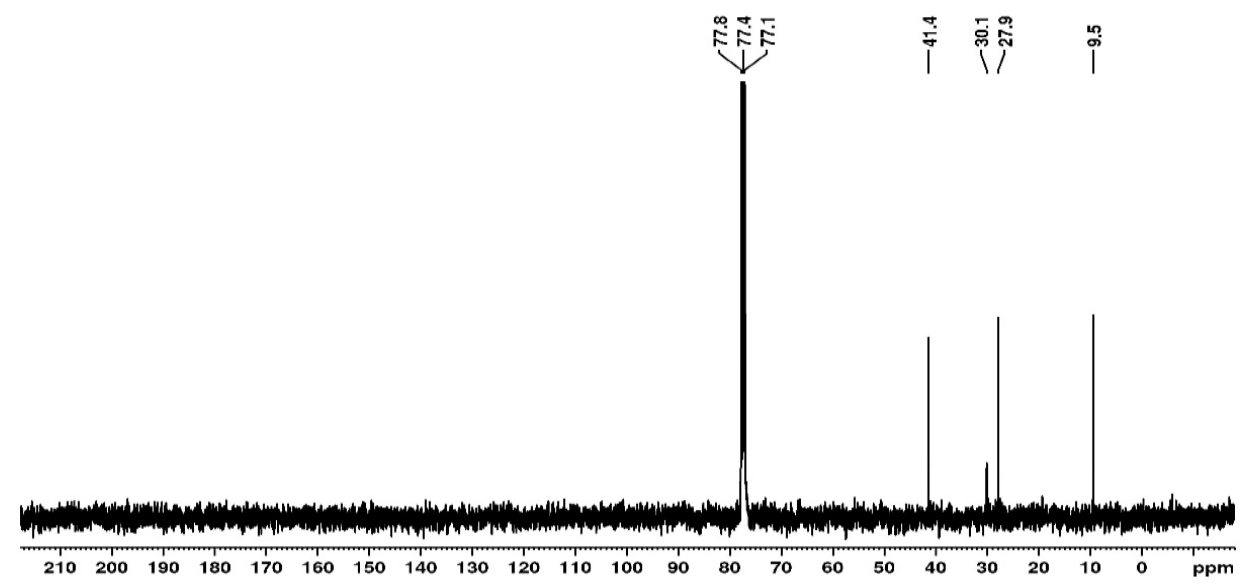

Figure S14. ${ }^{13} \mathrm{C}$ NMR spectrum of compound 8 in $\mathrm{CDCl}_{3}$.

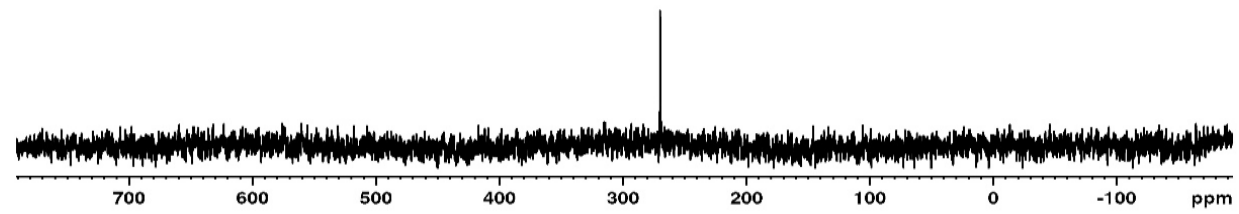

Figure S15. ${ }^{77}$ Se NMR spectrum of compound 8 in $\mathrm{CDCl}_{3}$. 


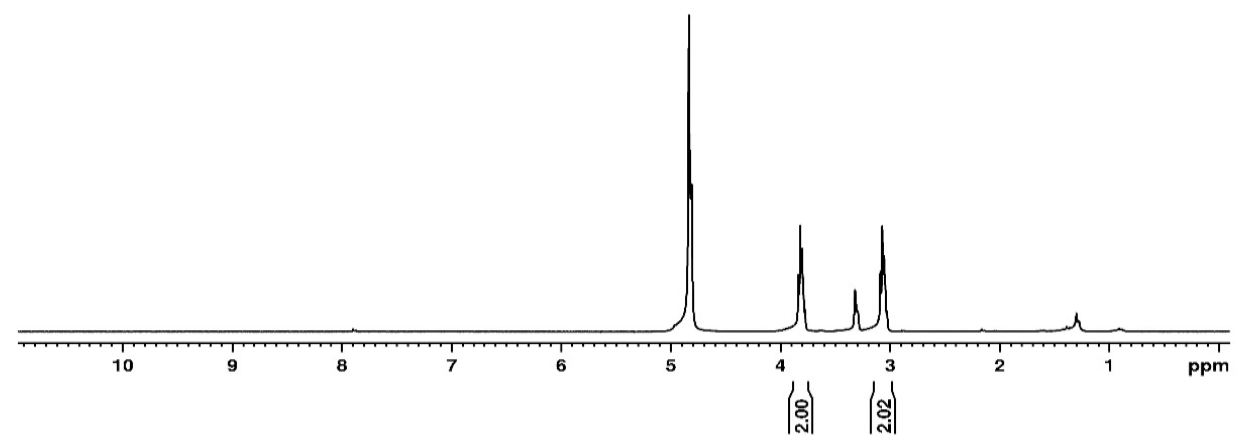

Figure S16. ${ }^{1} \mathrm{H}$ NMR spectrum of compound 9 in $\mathrm{CD}_{3} \mathrm{OD}$.

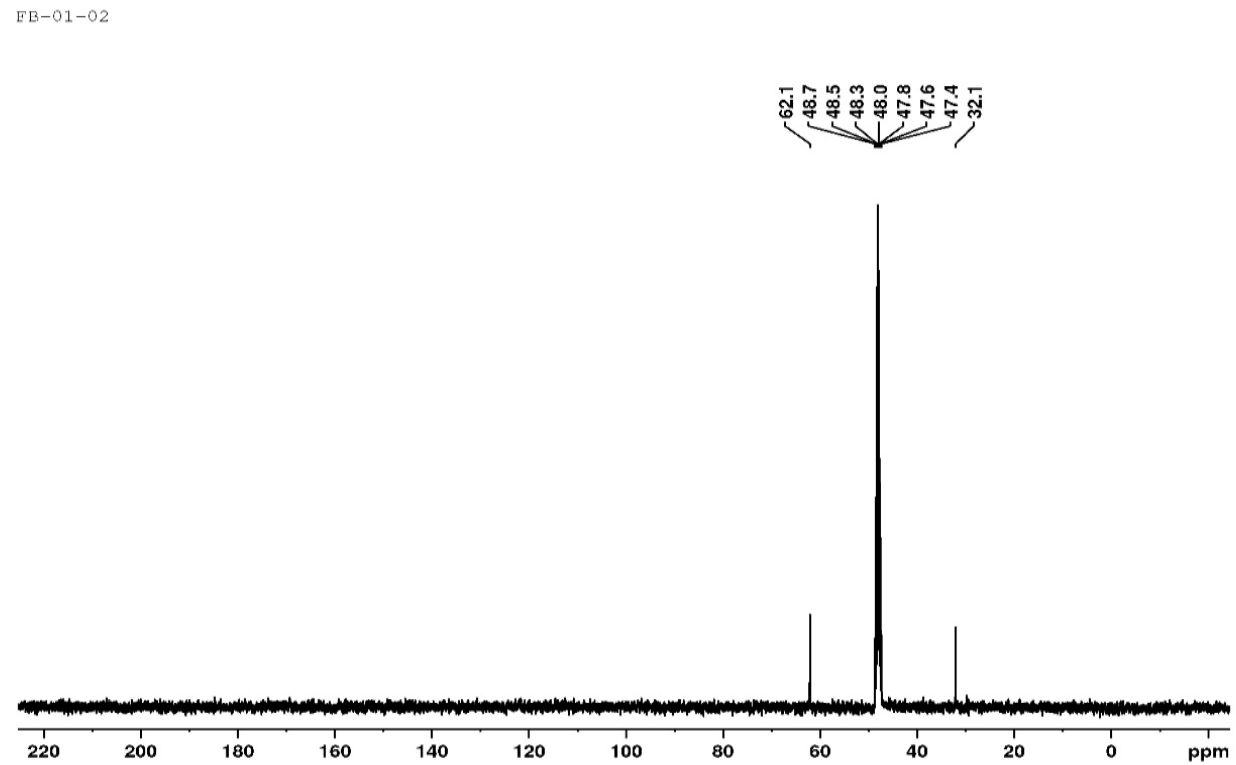

Figure S17. ${ }^{13} \mathrm{C}$ NMR spectrum of compound 9 in $\mathrm{CD}_{3} \mathrm{OD}$. 


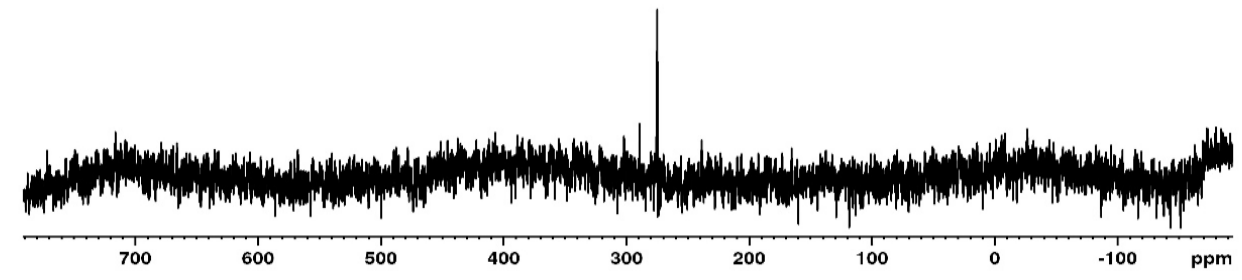

Figure S18. ${ }^{77} \mathrm{Se}$ NMR spectrum of compound 9 in $\mathrm{CD}_{3} \mathrm{OD}$.

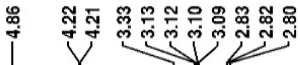

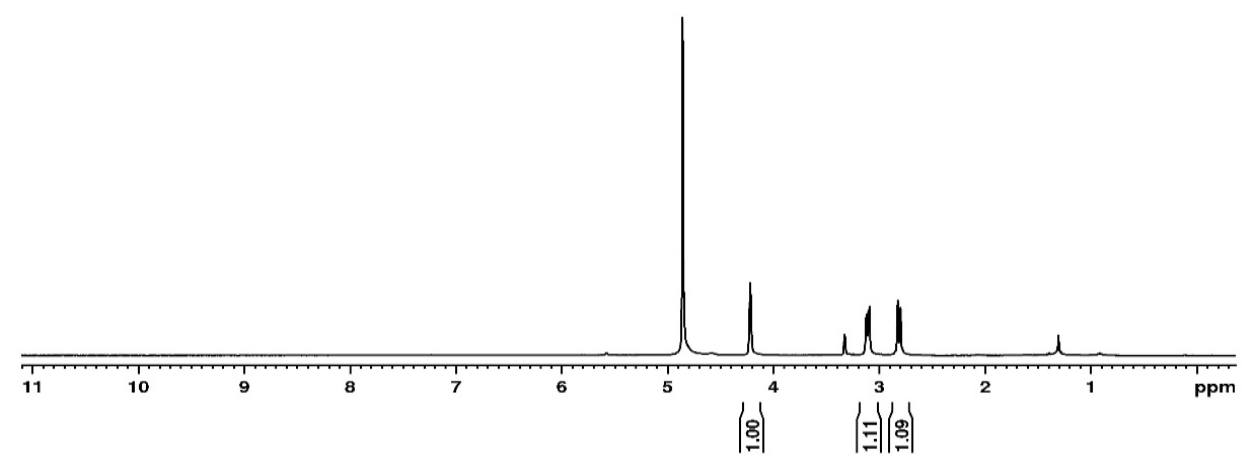

Figure S19. ${ }^{1} \mathrm{H}$ NMR spectrum of compound 10 in $\mathrm{CD}_{3} \mathrm{OD}$. 


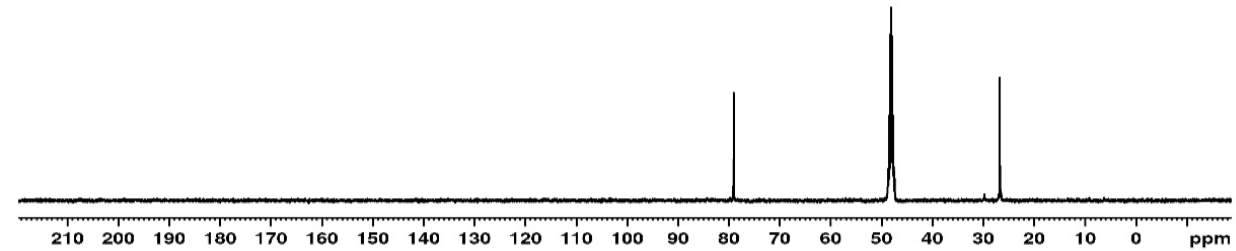

Figure S20. ${ }^{13} \mathrm{C}$ NMR spectrum of compound 10 in $\mathrm{CD}_{3} \mathrm{OD}$.

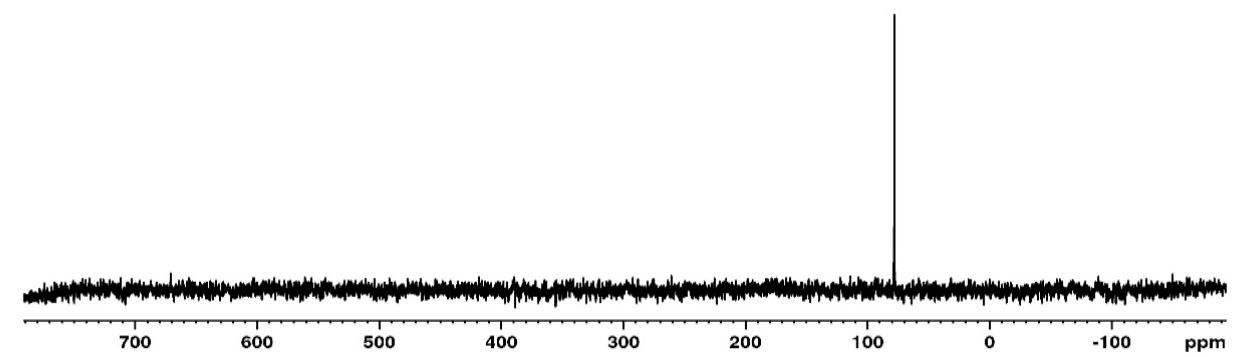

Figure S21. ${ }^{77}$ Se NMR spectrum of compound 10 in $\mathrm{CD}_{3} \mathrm{OD}$. 


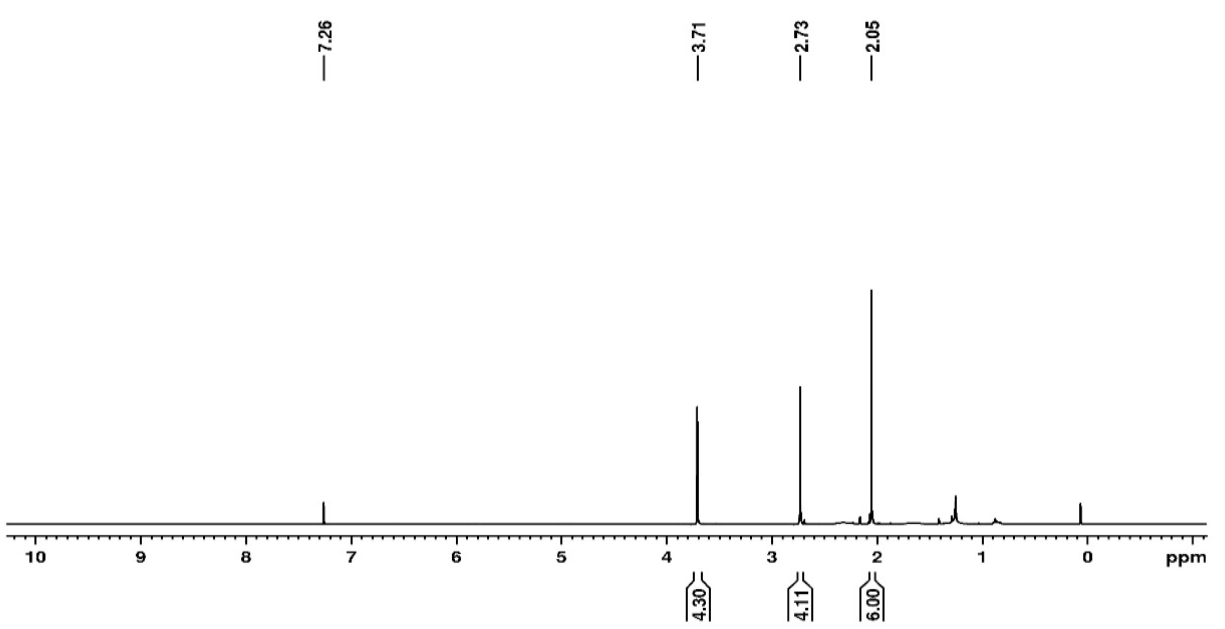

Figure S22. ${ }^{1} \mathrm{H}$ NMR spectrum of compound 11 in $\mathrm{CDCl}_{3}$.

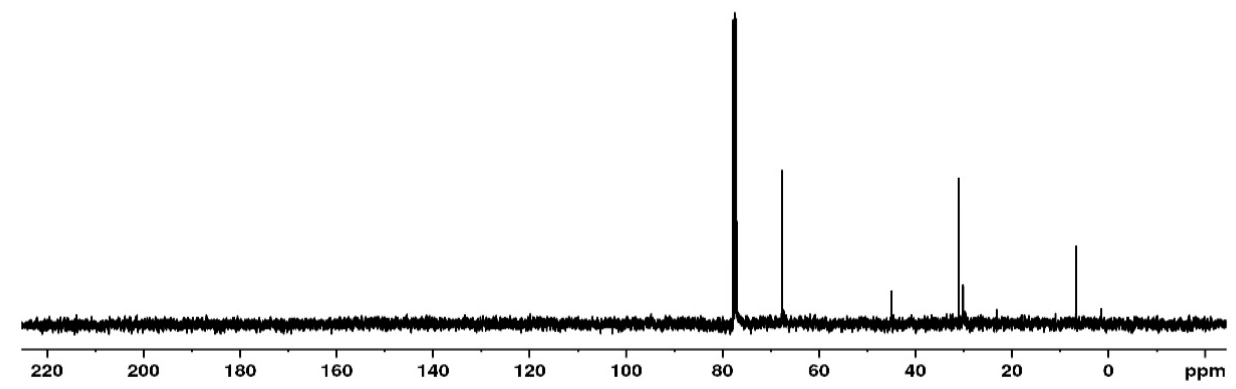

Figure S23. ${ }^{13} \mathrm{C}$ NMR spectrum of compound 11 in $\mathrm{CDCl}_{3}$. 


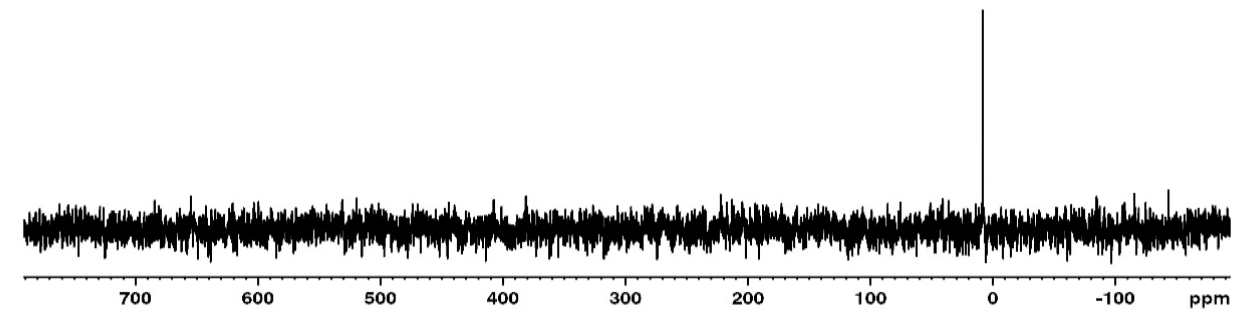

Figure S24. ${ }^{77}$ Se NMR spectrum of compound 11 in $\mathrm{CDCl}_{3}$.
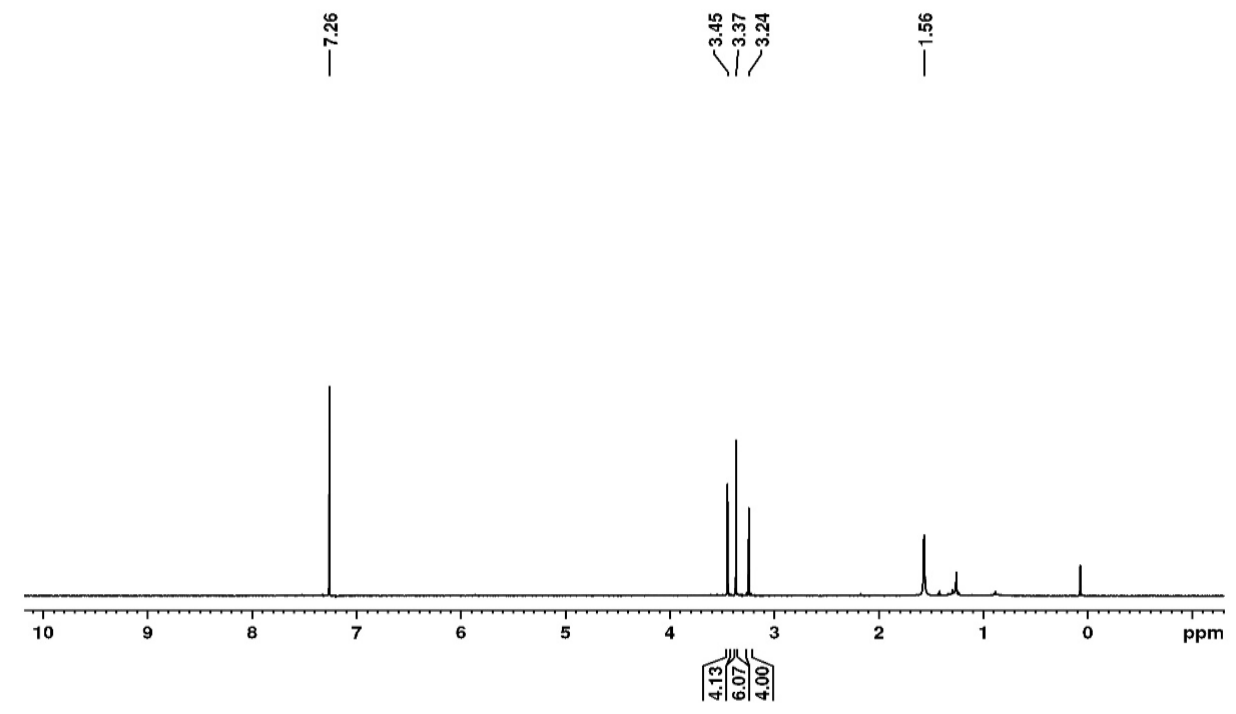

Figure S25. ${ }^{1} \mathrm{H}$ NMR spectrum of compound 12 in $\mathrm{CDCl}_{3}$. 


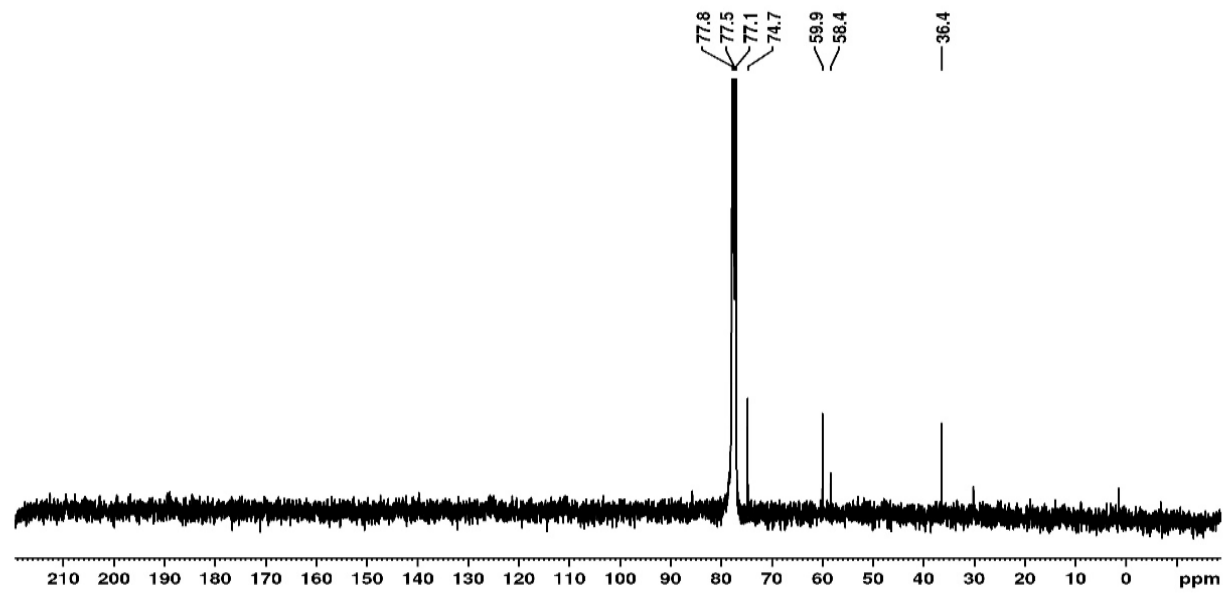

Figure S26. ${ }^{13} \mathrm{C}$ NMR spectrum of compound 12 in $\mathrm{CDCl}_{3}$.

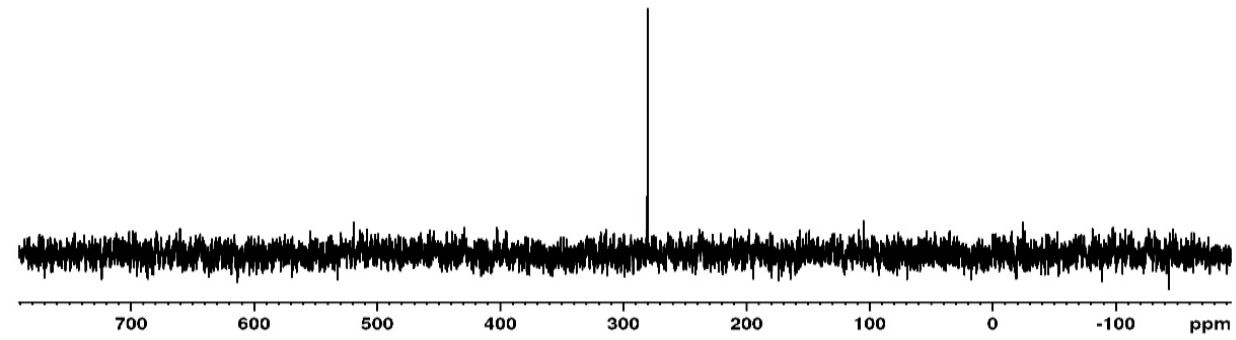

Figure S27. ${ }^{77}$ Se NMR spectrum of compound 12 in $\mathrm{CDCl}_{3}$. 


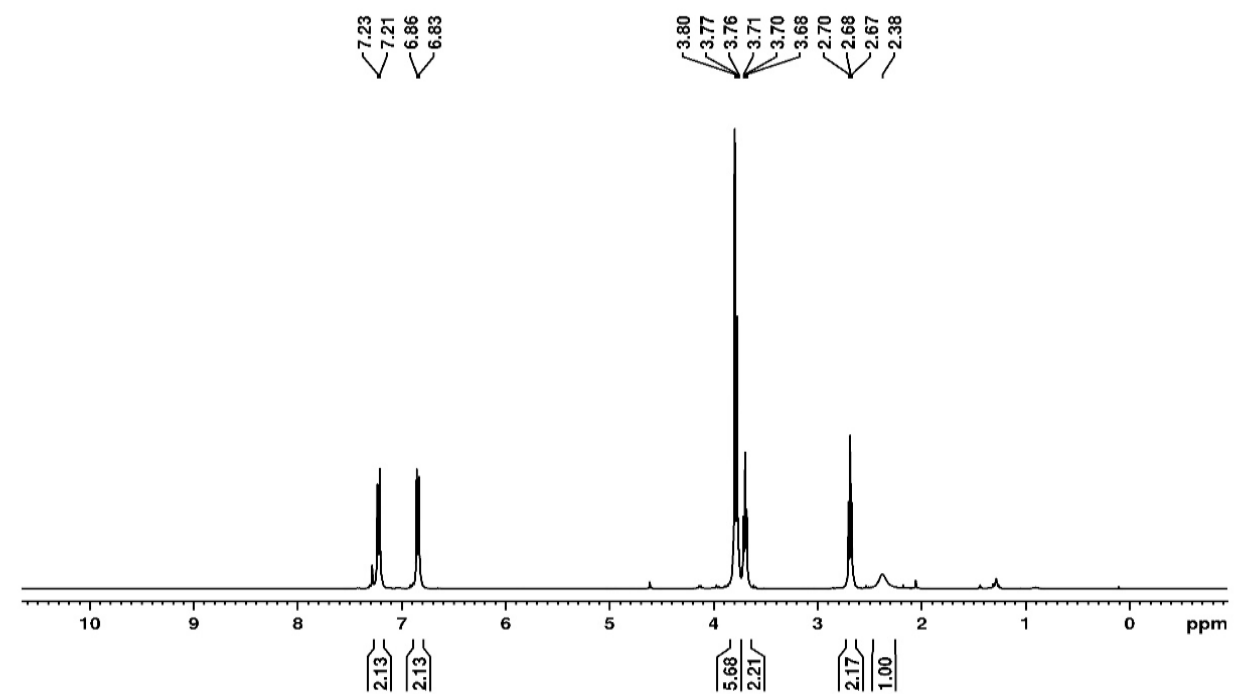

Figure S28. ${ }^{1} \mathrm{H}$ NMR spectrum of compound $\mathbf{S} 13$ in $\mathrm{CDCl}_{3}$.

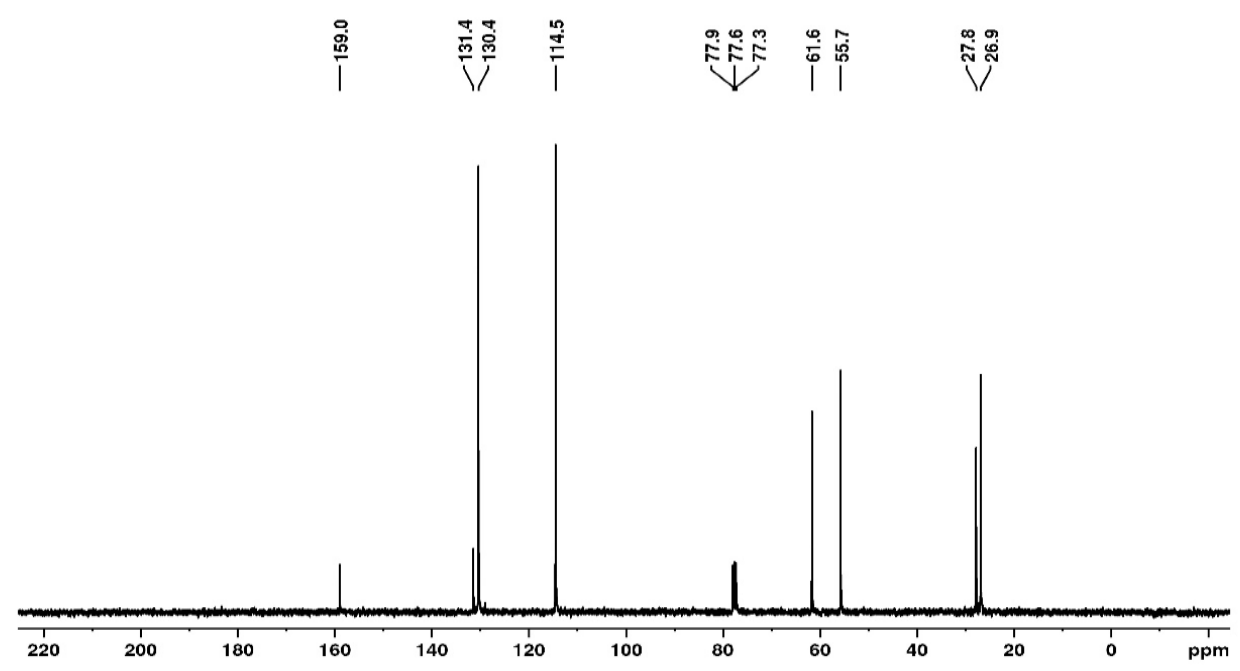

Figure S29. ${ }^{13} \mathrm{C}$ NMR spectrum of compound $\mathbf{S 1 3}$ in $\mathrm{CDCl}_{3}$. 


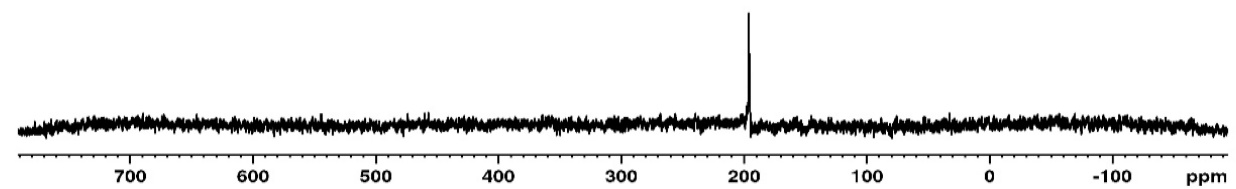

Figure S30. ${ }^{77}$ Se NMR spectrum of compound $\mathbf{S} 13$ in $\mathrm{CDCl}_{3}$. 

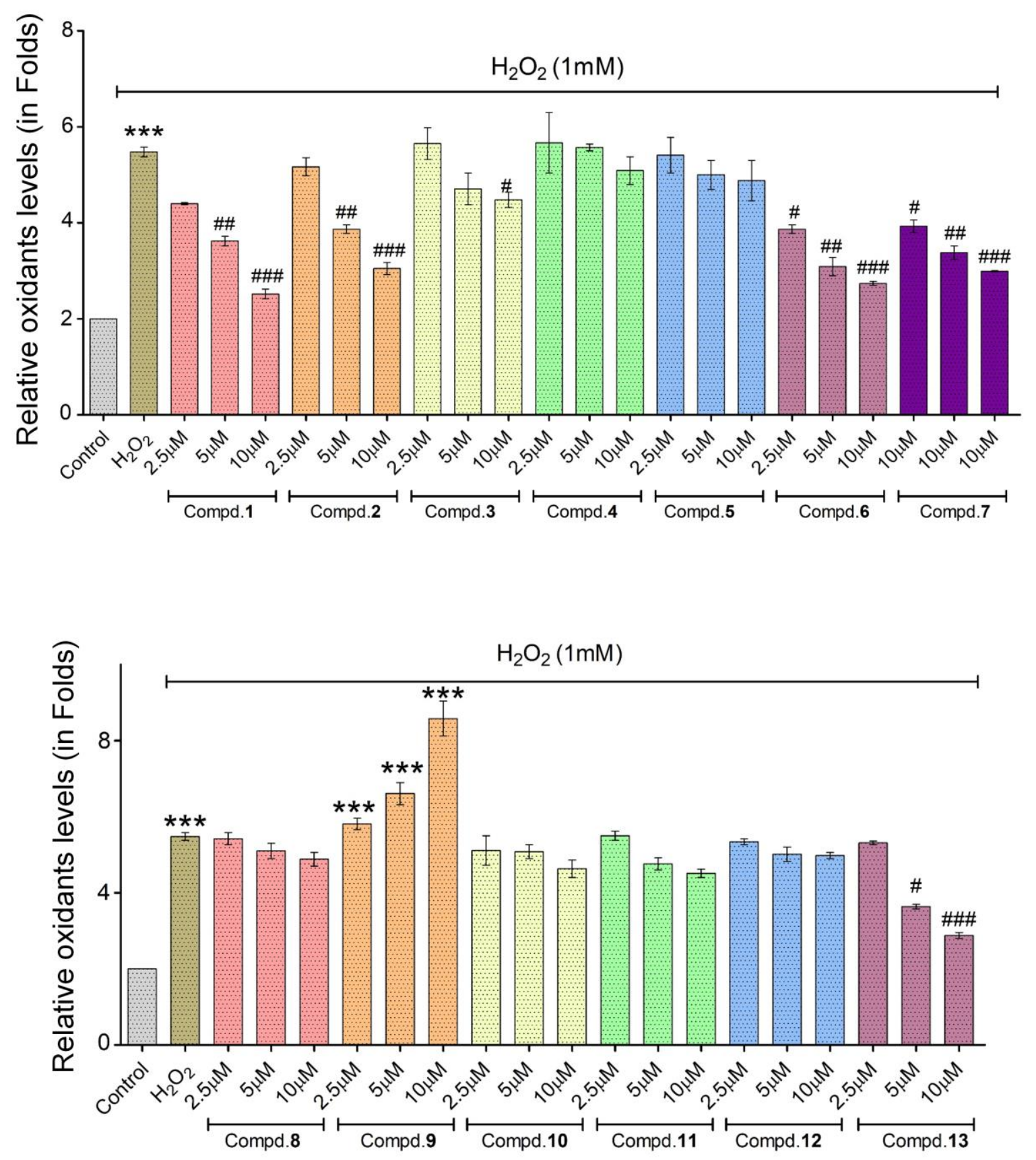

Figure S31. Dose-dependent evaluation of selenium compounds for their cytoprotective effect on $\mathrm{H}_{2} \mathrm{O}_{2}$-induced eryptosis. RBCs isolated from human blood were treated with $\mathrm{H}_{2} \mathrm{O}_{2}$ $(1 \mathrm{mM})$ in the presence and absence of dose-dependent selenium compounds ( $2.5 \mu \mathrm{M}$ to 10 $\mu \mathrm{M})$ for $1 \mathrm{~h}$ and evaluated by flow cytometric analysis of intracellular oxidants level using DCFH-DA. The data is presented as mean \pm SEM $(n=5)$ and analyzed using one-way ANOVA followed by Tukey's post hoc test, $\left.\mathrm{p}^{\star} / \#<0.05, \mathrm{p}^{\star *} / \# \#<0.01, \mathrm{p}^{\star \star *} / \# \# \#<0.001 ;{ }^{*}\right]$ significant compared to untreated RBCs; [\#] significant compared to $\mathrm{H}_{2} \mathrm{O}_{2}$ treated RBCs. 

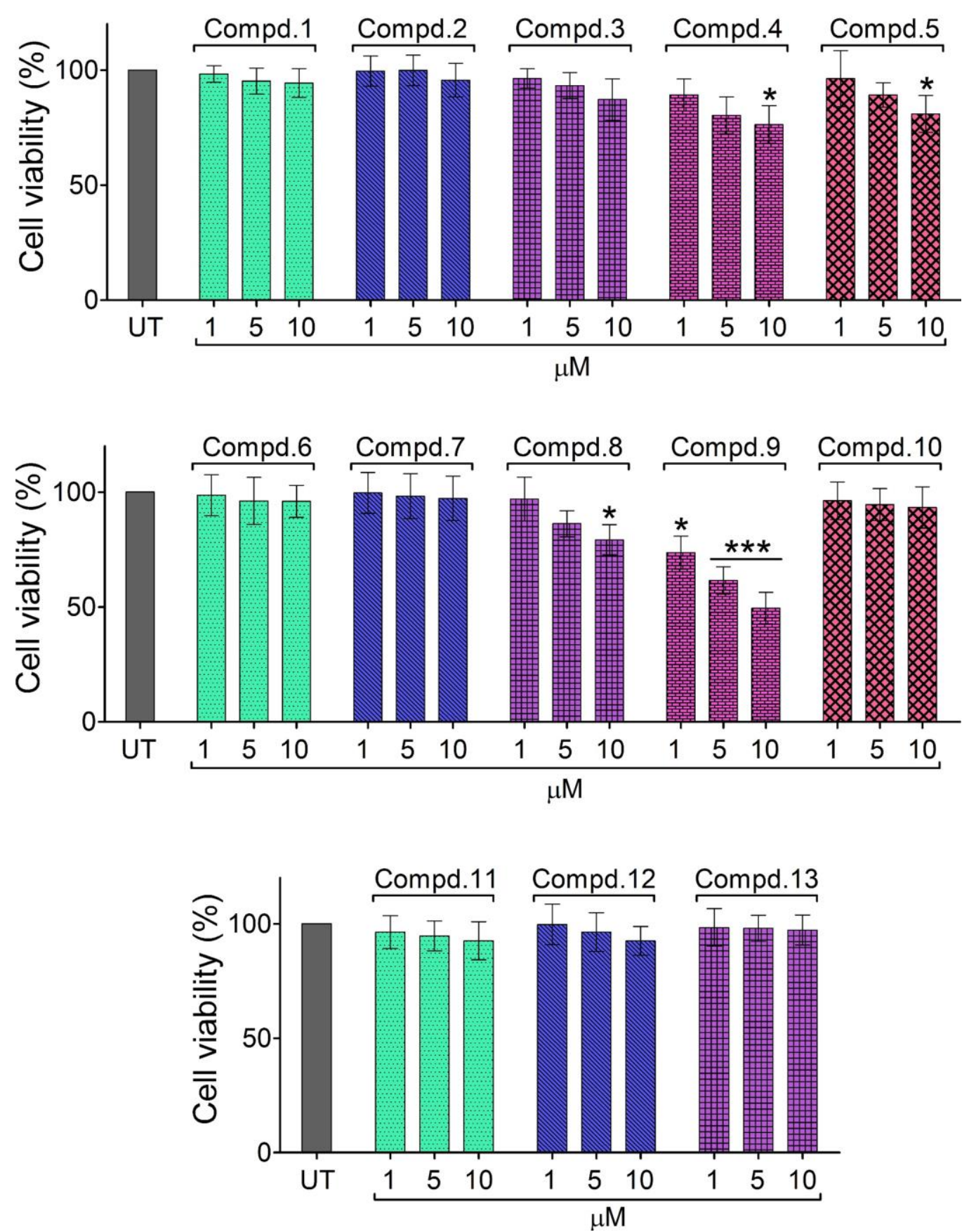

Figure S32. The relative cell viability of RBCs after incubation with selenium compounds. Flow cytometric cell viability analysis of RBCs treated with various doses $(1 \mu \mathrm{M}, 5 \mu \mathrm{M}$ and $10 \mu \mathrm{M}$ ) of selenium compounds (1 to 13) for $6 \mathrm{~h}$ using calcein-AM. The data is presented as mean \pm SEM $(n=5)$ and analyzed using one-way ANOVA followed by Tukey's post hoc test, $\mathrm{p}^{*}<0.05, \mathrm{p}^{\star *}<0.01, \mathrm{p}^{* * *}<0.001 ;\left[{ }^{*}\right]$ significant compared to untreated RBCs. 


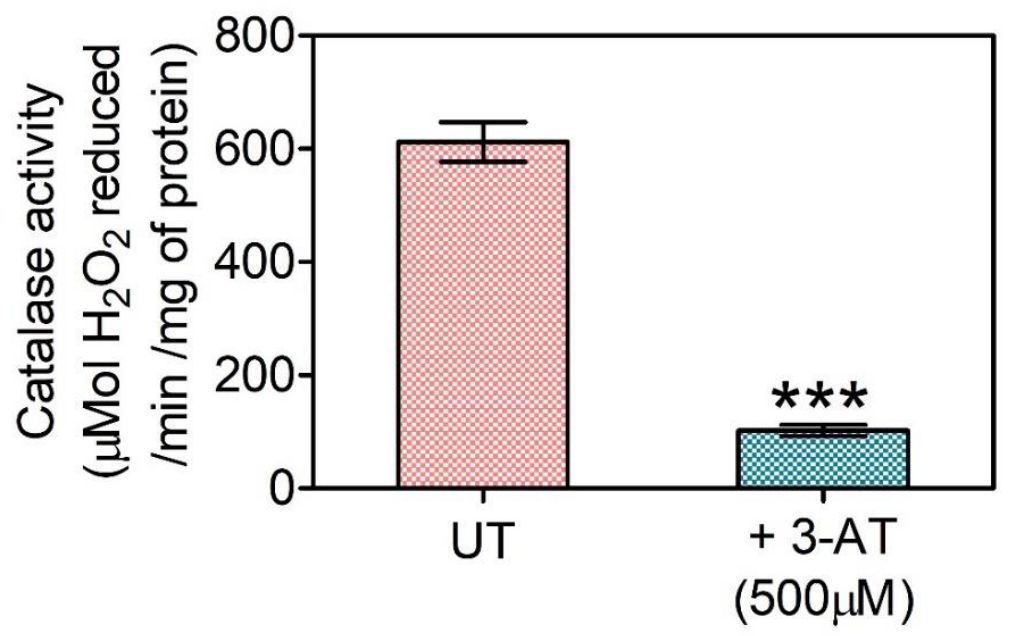

Figure S33. Estimation of catalase activity in the erythrocytes after treatment with 3-AT (catalase inhibitor) $(500 \mu \mathrm{M})$ for $1 \mathrm{~h}$ at $37^{\circ} \mathrm{C}$. The data is presented as mean \pm SEM $(n=5)$ and analyzed using one-way ANOVA followed by Tukey's post hoc test, $\mathrm{p}^{\star * *}<0.001$; [ $\left.{ }^{*}\right]$ significant compared to untreated (UT) RBCs.

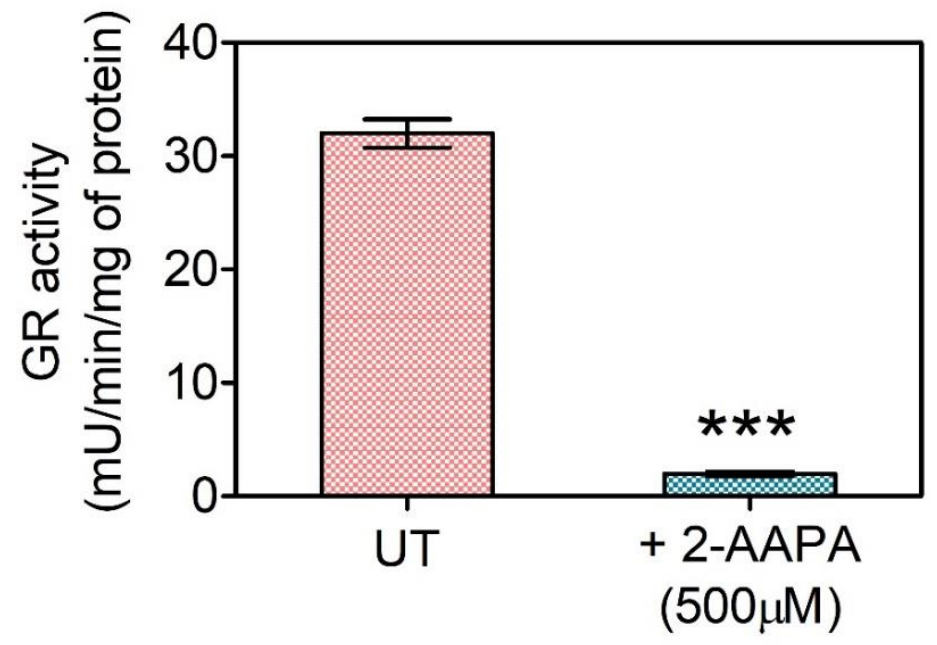

Figure S34. Estimation of glutathione reductase (GR) activity in the erythrocytes after treatment with 2-AAPA (GR inhibitor) $(500 \mu \mathrm{M})$ for $1 \mathrm{~h}$ at $37^{\circ} \mathrm{C}$. The data is presented as mean \pm SEM $(n=5)$ and analyzed using one-way ANOVA followed by Tukey's post hoc test, $\left.\mathrm{p}^{* \star *}<0.001 ;{ }^{*}\right]$ significant compared to untreated (UT) RBCs. 


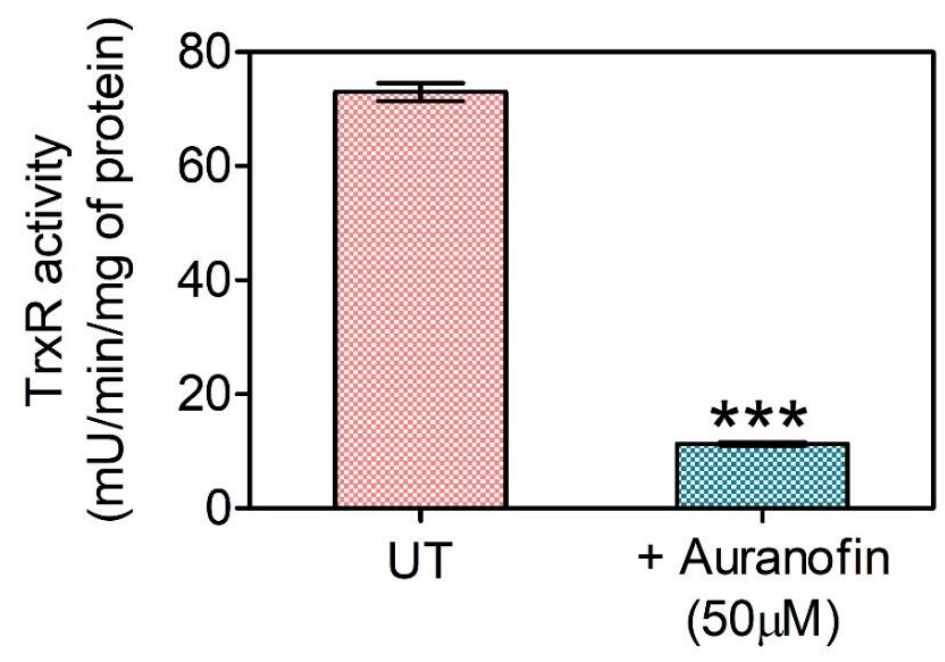

Figure S35. Estimation of thioredoxin reductase (TrxR) activity in the erythrocytes after the treatment with auranofin (TrxR inhibitor) $(50 \mu \mathrm{M})$ for $1 \mathrm{~h}$ at $37^{\circ} \mathrm{C}$. The data is presented as mean \pm SEM $(n=5)$ and analyzed using one-way ANOVA followed by Tukey's post hoc test, $\mathrm{p}^{* * *}<0.001 ;\left[^{*}\right]$ significant compared to untreated (UT) RBCs.
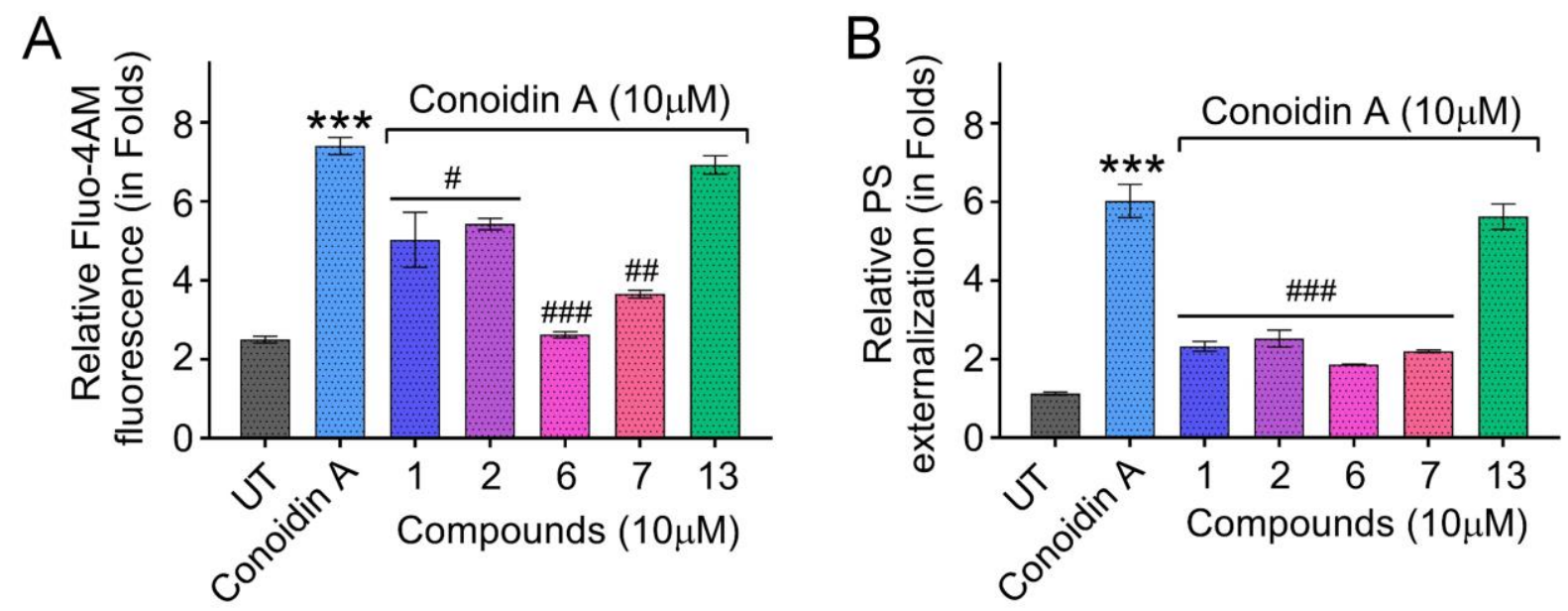

Figure S36. Isolated human RBCs were pre-incubated with conoidin A for 30 min followed by treatment with selenium compounds. The cells were analyzed for (A) Intracellular $\mathrm{Ca}^{2+}$ level using Fluo-4AM and (B) PS externalization using annexin V-FITC. The data is presented as mean \pm SEM $(n=5)$ and analyzed using one-way ANOVA followed by Tukey's post hoc test, $\left.\mathrm{p}^{\star} / \#<0.05, \mathrm{p}^{\star *} / \# \#<0.01, \mathrm{p}^{* \star *} / \# \# \#<0.001 ;{ }^{\star}\right]$ significant compared to untreated RBCs; [\#] significant compared to conoidin-A treated RBCs. 

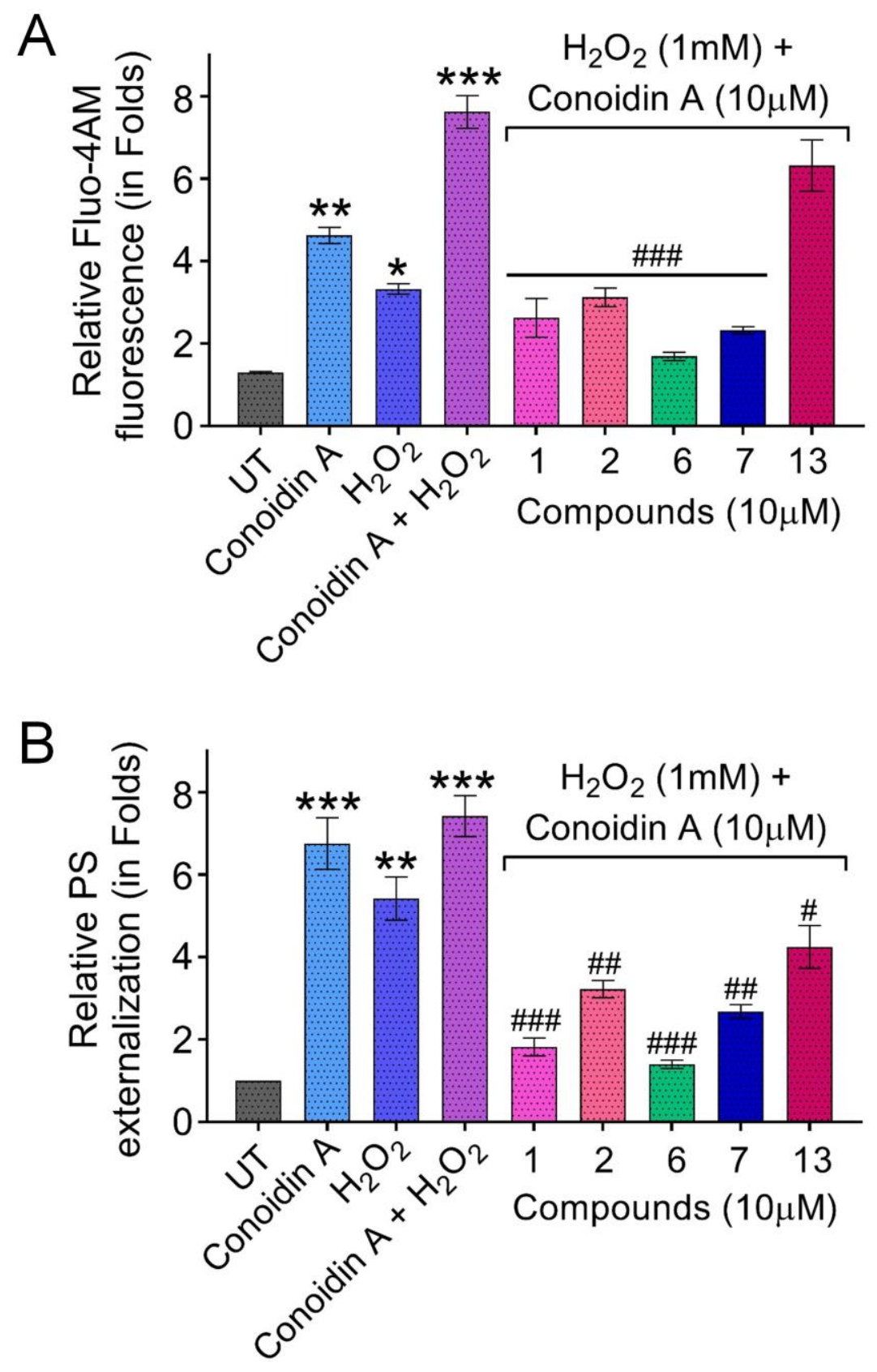

Figure S37. RBCs were treated with $\mathrm{H}_{2} \mathrm{O}_{2}$ and selenium compounds pre-incubated with conoidin-A for 30 min and evaluated for $(A)$ Intracellular $\mathrm{Ca}^{2+}$ level using Fluo-4AM and $=(B)$ PS externalization using annexin V-FITC. Data is represented as the relative oxidant level (in folds) of treated cells as compared to that of untreated cells. The data is presented as mean \pm SEM $(n=5)$ and analyzed using one-way ANOVA followed by Tukey's post hoc test, $\mathrm{p}^{*} / \#<$ $0.05, \mathrm{p}^{\star \star} / \# \#<0.01, \mathrm{p}^{\star \star *} / \# \# \#<0.001 ;\left[{ }^{\star}\right]$ significant compared to untreated RBCs; [\#] significant compared to conoidin- $\mathrm{A}$ and $\mathrm{H}_{2} \mathrm{O}_{2}$ treated RBCs. 

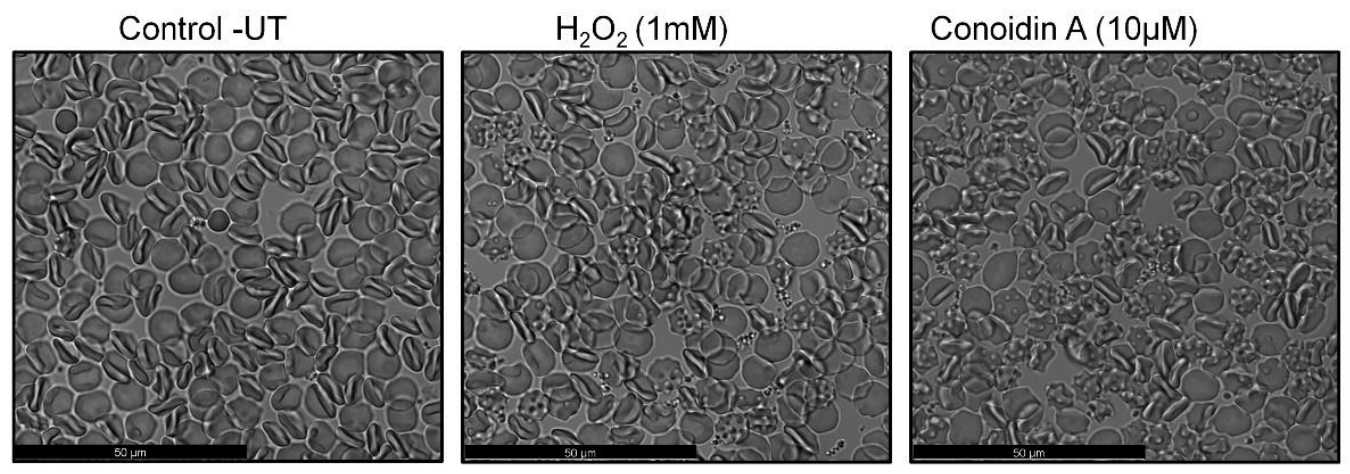

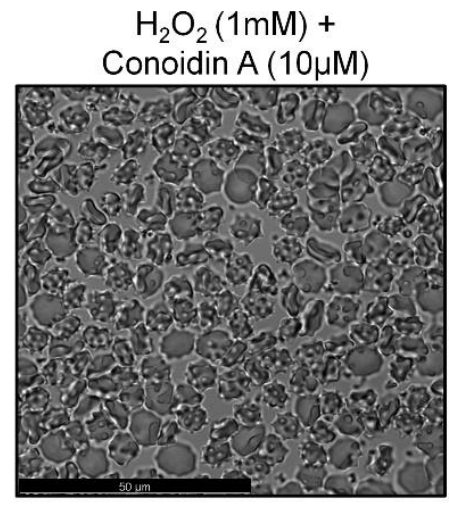

$\mathrm{H}_{2} \mathrm{O}_{2}(1 \mathrm{mM})+$

Conoidin A $(10 \mu \mathrm{M})$

+ Comp.1 $1(10 \mu \mathrm{M})$

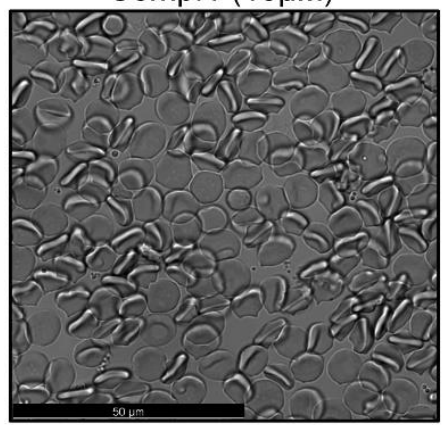

$\mathrm{H}_{2} \mathrm{O}_{2}(1 \mathrm{mM})+$

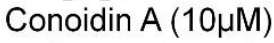

Conoidin $\mathrm{A}(10 \mu \mathrm{M})$

+ Comp. $6(10 \mu \mathrm{M})$

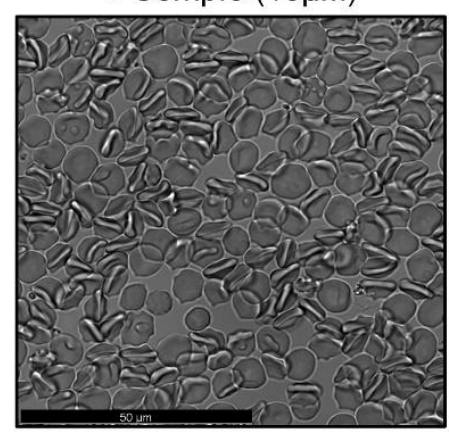

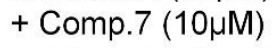

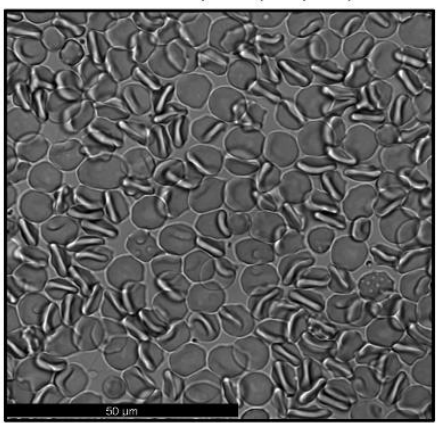

$\mathrm{H}_{2} \mathrm{O}_{2}(1 \mathrm{mM})+$

Conoidin $\mathrm{A}(10 \mu \mathrm{M})$

+ Comp. $2(10 \mu \mathrm{M})$

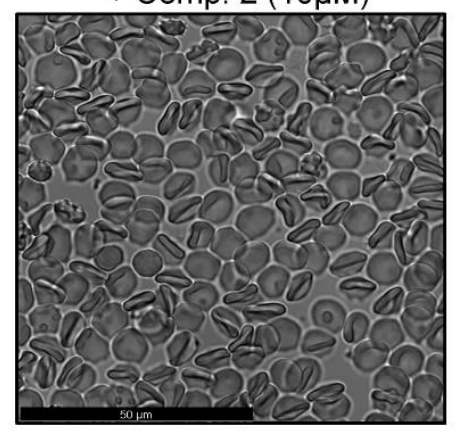

$\mathrm{H}_{2} \mathrm{O}_{2}(1 \mathrm{mM})+$

Conoidin $\mathrm{A}(10 \mu \mathrm{M})$

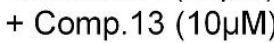

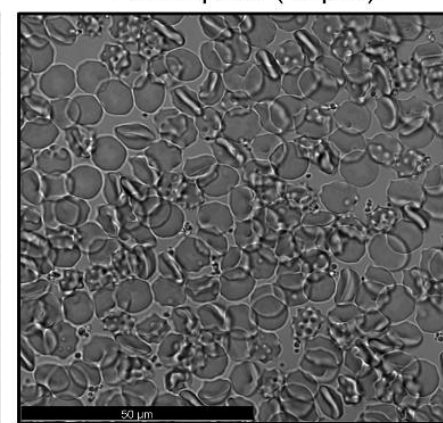

Figure S38. Morphological changes in RBCs with $\mathrm{H}_{2} \mathrm{O}_{2}$, conoidin $A$ and selenium compounds treatment using confocal microscopic (DIC images). Images were acquired with a Leica TCS SP8 confocal microscopy and were further analysed and extracted using LAS $X$ (Leica) software. 
A

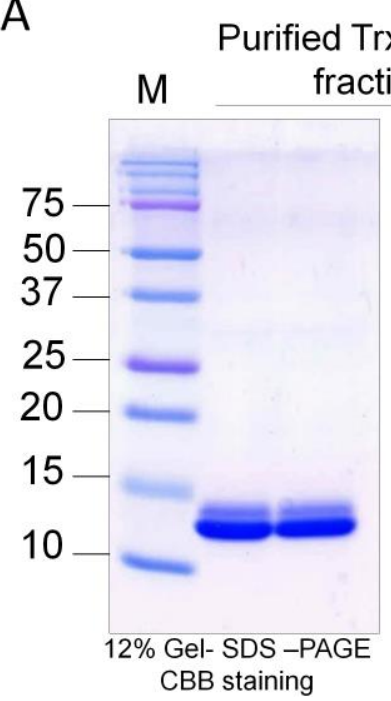

B

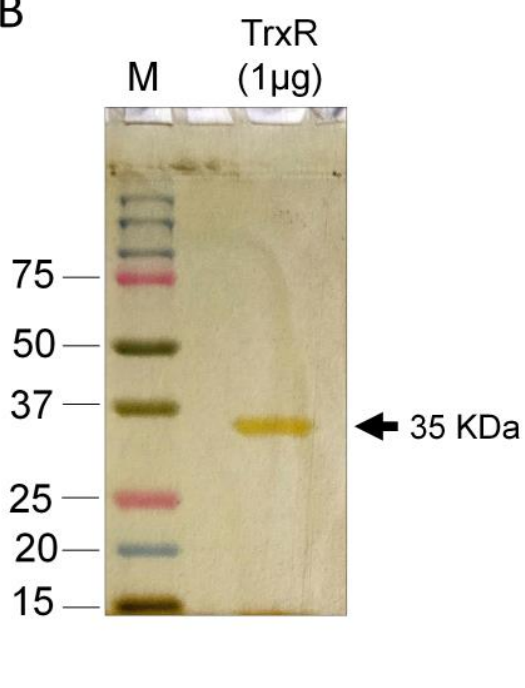

Figure S39. Expression and purification of thioredoxin (Trx)-His in E.coli. (A) SDS-PAGE for Trx stained with Coomassie blue and immunostaining using Trx-specific antibody (Anti-TRx Ab (1:750 dilution)). (B) Silver staining to confirm the purity of thioredoxin reductase (TrxR) (Merck-598502) used in this study.

Table S1. In vitro Prx2 activity of compounds 1, 2, 6 and 7.

\begin{tabular}{|l|l|l|}
\hline S. No & Conditions & Initial Rate $\left(\mu \mathrm{M} \cdot \mathrm{min}^{-1}\right)$ \\
\hline 1 & NADPH + Trx + TrxR & $0.87 \pm 0.01$ \\
\hline 2 & NADPH + Trx + TrxR $+\mathrm{H}_{2} \mathrm{O}_{2}$ & $0.80 \pm 0.01$ \\
\hline 3 & $\mathrm{NADPH}+\operatorname{Trx}+\operatorname{TrxR}+\mathrm{H}_{2} \mathrm{O}_{2}+1$ & $3.49 \pm 0.02$ \\
\hline 4 & $\mathrm{NADPH}+\operatorname{Trx}+\operatorname{TrxR}+\mathrm{H}_{2} \mathrm{O}_{2}+2$ & $3.24 \pm 0.01$ \\
\hline 5 & $\mathrm{NADPH}+\operatorname{Trx}+\operatorname{TrxR}+\mathrm{H}_{2} \mathrm{O}_{2}+6$ & $5.68 \pm 0.02$ \\
\hline 6 & NADPH $+\operatorname{Trx}+\operatorname{TrxR}+\mathrm{H}_{2} \mathrm{O}_{2}+7$ & $4.69 \pm 0.02$ \\
\hline
\end{tabular}

Assay conditions: $25 \mathrm{mM}$ potassium phosphate buffer with $2 \mathrm{mM}$ EDTA (pH 7.0), $5 \mu \mathrm{M}$ Trx, $9 \mathrm{nM}$ TrxR and $150 \mu \mathrm{M}$ NADPH. The change in the absorbance of NADPH was monitored at $340 \mathrm{~nm}$. For the reduction of $\mathrm{H}_{2} \mathrm{O}_{2}$ by selenium compounds, $500 \mu \mathrm{M} \mathrm{H}_{2} \mathrm{O}_{2}$ was used and the initial rates were calculated from the decrease in the absorption of NADPH using the molar extinction coefficient of NADPH $6.22 \mathrm{mM}^{-1} \mathrm{~cm}^{-1}$. 


\section{References:}

(1) Bhabak, K. P.; Mugesh, G. Synthesis, characterization, and antioxidant activity of some ebselen analogues. Chem. Eur. J. 2007, 13 (16), 4594.

(2) Klayman, D. L.; Griffin, T. S. Reaction of selenium with sodium borohydride in protic solvents. A Facile Method for the introduction of selenium into organic molecules. J. Am. Chem. Soc. 1973, 95 (1), 197-199.

(3) (a) Iwaoka, M.; Takahashi, T.; Tomoda, S. Syntheses and structural characterization of water-soluble selenium reagents for the redox control of protein disulfide bonds. Heteroat. Chem. 2001, 12, 293. (b) Kumakura, F.; Mishra, B.; Indira Priyadarsini, K.; Iwaoka, M. A Water-Soluble Cyclic Selenide with Enhanced Glutathione Peroxidase-Like Catalytic Activities. Eur. J. Org. Chem. 2010, 440. (c) Arai, K.; Ueno, H.; Asano, Y.; Chakrabarty, G.; Shimodaira, S.; Mugesh, G.; Iwaoka, M. ChemBioChem. 2018, 19 (3), 207.

(4) (a) Bergson, G. The Selenium Analogue of 6-Thioctic Acid. Acta Chem. Scand. 1957, 11, 1607. (b) Sato, R.; Kimura, T. Science of Synthesis, 2008, 39, 1103.

(5) (a) Ansari, F. A.; Ali, S.; N Mahmood, R. Sodium nitrite-induced oxidative stress causes membrane damage, protein oxidation, lipid peroxidation and alters major metabolic pathways in human erythrocytes. Toxicol. In Vitro. 2015, 29 (7), 1878-1886. (b) Roy, A. Sil, P. C. Tertiary butyl hydroperoxide induced oxidative damage in mice erythrocytes: Protection by taurine. Pathophysiology, 2012,19 (2), 137-148. 